JOÃO PAULO RAMOS JACOB

\title{
JUSTIÇA ELEITORAL: \\ ENTRE O AUTORITARISMO E A DEMOCRACIA
}

\author{
Dissertação de Mestrado
}

Orientador: Professor Titular Dr. Enrique Ricardo Lewandowski

UNIVERSIDADE DE SÃO PAULO

FACULDADE DE DIREITO

São Paulo - SP

2018 


\title{
JOÃO PAULO RAMOS JACOB
}

\section{JUSTIÇA ELEITORAL: \\ ENTRE O AUTORITARISMO E A DEMOCRACIA}

\begin{abstract}
Dissertação apresentada à Banca Examinadora do Programa de Pós-Graduação em Direito, da Faculdade de Direito da Universidade de São Paulo, como exigência parcial para obtenção do título de Mestre em Direito, na área de concentração Direito do Estado, sob a orientação do Prof. Titular Dr. Enrique Ricardo Lewandowski.
\end{abstract}

UNIVERSIDADE DE SÃO PAULO

FACULDADE DE DIREITO

São Paulo - SP

2018 
Autorizo a reprodução e divulgação total ou parcial deste trabalho, por qualquer meio convencional ou eletrônico, para fins de estudo e pesquisa, desde que citada a fonte.

\section{Catalogação da Publicação}

Jacob, João Paulo Ramos

Justiça eleitoral: entre o autoritarismo e a democracia / João Paulo Ramos Jacob -- São Paulo: USP / Faculdade de Direito, 2018.

$264 f$.

Orientador: Professor Titular Dr. Enrique Ricardo Lewandowski.

Dissertação (Mestrado), Universidade de São Paulo, USP, Programa de Pós-Graduação em Direito, Direito do Estado, 2018.

1. Justiça Eleitoral. 2. Processo Eleitoral. 3. Estado Democrático de Direito. I. Lewandowski, Enrique Ricardo. II. Título. 


\title{
FOLHA DE APROVAÇÃO
}

Nome: JACOB, João Paulo Ramos.

Título: Justiça Eleitoral: Entre o Autoritarismo e a Democracia.

Dissertação apresentada à Faculdade de Direito da Universidade de São Paulo para obtenção do título de Mestre em Direito.

Aprovado em:

\author{
Banca Examinadora
}

Prof. Dr.

Instituição:

Julgamento:

Prof. Dr.

Instituição:

Julgamento:

Prof. Dr.

Instituição:

Julgamento: 
Ao meu avô, Paulo Jacob (in memoriam) 


\section{AGRADECIMENTOS}

Chega-se ao final de uma longa jornada, iniciada nos idos de 2015, aos 23 anos, e concluída agora com uma lista de agradecimentos meramente exemplificativa, tamanha foi a troca com as pessoas que participaram desse processo de amadurecimento acadêmico, pessoal e profissional.

Agradeço a Deus, por ter me dado a dádiva de seguir adiante mesmo com as maiores adversidades possíveis, sempre com saúde e fé, que nunca me faltaram.

Aos meus pais, Paulo e Sheila Jacob, ao meu irmão Vinícius e a minha avó Marilda, por terem me dado todo o suporte necessário durante minha estada em São Paulo, sem nunca, por um segundo sequer, duvidarem que concluiria esta missão.

Ao meu orientador, Prof. Ricardo Lewandowski, pela inigualável oportunidade que me concedeu ao me acolher e ao permitir que o trabalho fosse elaborado de acordo com meus ideais, daquilo que se propôs pesquisar, sempre com balizas importantes para que 0 resultado final pudesse ser algo academicamente relevante.

Aproveito para agradecer ao seu gabinete, na pessoa da Dra. Ana Maria, que, diante das dificuldades de agenda, me auxiliou com uma presteza ímpar para que se pudesse agilizar trâmites dentro de prazos tão exíguos.

Ao Prof. Eros Grau, com quem tenho a honra de desfrutar da amizade e que muito me fez brilhar os olhos para ingressar no Largo de São Francisco. Agradeço pela palavra sempre amiga, disposta a incentivar o conhecimento, e por ter despertado em mim a vontade do "fazer" acadêmico.

Ao amigo e Prof. de Graduação Érico Desterro, da Universidade Federal do Amazonas, pela companhia que me fez semanalmente nas aulas da pósgraduação.

Estendo meus agradecimentos a uma pessoa fundamental no despertar desse processo: José Alberto Simonetti, amigo querido e grande advogado amazonense.

Ao Prof. Robério Braga, pela solicitude em dar ideias, contornos e em ceder parte de seu acervo para as pesquisas do presente trabalho.

Aos meus amigos, tanto de São Paulo quanto do Amazonas, das aulas ou da vida cotidiana, fica aqui meu muito obrigado. 
"Não é bastante que haja controle do povo pelo governo, mas controle do governo pelo povo". (RIBEIRO, Fávila. Direito eleitoral. Rio de Janeiro: Forense, 1988, p. 41). 
JACOB, João Paulo. Justiça Eleitoral: entre o autoritarismo e a democracia. 2018. 264f. Dissertação (Mestrado em Direito) - Faculdade de Direito, Universidade de São Paulo, São Paulo, 2018.

\section{RESUMO}

A presente dissertação trata da importância da criação e da evolução da Justiça Eleitoral Brasileira para a manutenção da democracia no país. O tema mostra-se relevante, considerando a instabilidade da história política brasileira, marcada por momentos de tensão entre a democracia e o autoritarismo. Essa oscilação certamente colaborou para o atraso do desenvolvimento da Justiça Eleitoral, sendo que, em alguns períodos, simplesmente a desconsiderou, causando assim um cenário de insegurança jurídica e de ameaça ao Estado Democrático. Dessa forma, o objetivo do presente estudo é analisar o desenvolvimento da Justiça Eleitoral, evidenciando como o órgão partiu de uma posição de passividade frente aos desmandos e arbítrios das autoridades, para uma posição mais autônoma, atuante e decisiva no processo eleitoral brasileiro, razão pela qual atualmente ocupa um lugar de relevo na luta pela consolidação do Estado Democrático de Direito e pela preservação da verdade eleitoral. Para tanto, realizou-se uma análise diacrônica da evolução da Justiça Eleitoral, examinando a jurisprudência e a doutrina nacionais, bem como estudou-se comparativamente os sistemas eleitorais na realidade latinoamericana. Em sua conclusão, este trabalho destaca a importância do reconhecimento da evolução da Justiça Eleitoral Brasileira, a necessidade de uma maior especialização de seus magistrados e a possibilidade de concessão de maior autonomia ao órgão, nos moldes dos sistemas delineados em países como Uruguai e Costa e Rica.

Palavras-Chave: Justiça Eleitoral. Processo Eleitoral. Evolução. Estado Democrático de Direito. 
JACOB, João Paulo. Electoral Justice: between authoritarianism and democracy. 2018. 264p. Dissertation (Master's Degree in Law) - Law school, University of São Paulo, São Paulo, 2018.

\begin{abstract}
The present dissertation focus on the importance of the creation and evolution of the Brazilian Electoral Justice for the support of democracy in the country. The topic has shown to be relevant, considering the instability of Brazilian political history, marked by moments of tension between democracy and the authoritarianism. This variation certainly contributed to the delay in the development of the Electoral Justice, and in some periods, it was simply disregarded, thus causing a scenario of legal insecurity and threat to the Democratic State. Therefore, the purpose of this research is to demonstrate the development of Electoral Justice, evidencing how it started in a position of passivity front to the abuse and will of the authorities, for an active and decisive position in the Brazilian electoral process, which is the reason why for which it currently occupies a prominent place in the fight for the consolidation of the Democratic State of Law and preservation of the electoral truth. For this purpose, a diachronic analysis of the evolution of Electoral Justice was carried out, examining national jurisprudence and doctrine, as well as comparatively studying the electoral systems in the Latin American reality. In conclusion, this study highlights the importance of recognizing the evolution of the Brazilian Electoral Justice, the need for a better specialization of its magistrates and the possibility of granting greater autonomy to the body, in the way outlined in countries such as Uruguay and Costa Rica.
\end{abstract}

Keywords: Electoral justice. The Electoral process. Evolution. Democratic state of Law. 


\section{LISTA DE ILUSTRAÇÕES}

Figura 1 - Níveis de votação para escolha de deputados para as Cortes de

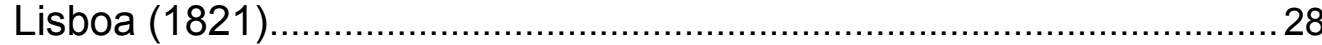

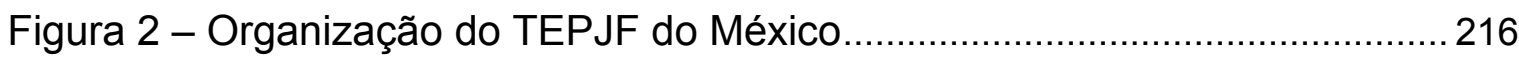

Figura 3 - Organização do Judiciário Eleitoral Argentino .......................................223

Gráfico 1 - Resultados eleitorais dos pleitos de 1933 e 1934 (médias

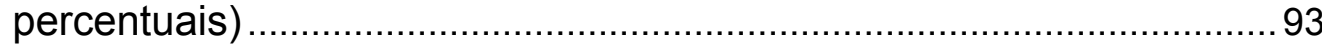

Quadro 1 - Alcance da Ordenação do Reino..........................................................20 


\section{LISTA DE TABELAS}

Tabela 1 - Situação organizacional do poder eleitoral em cada um dos países analisados

Tabela 2 - Situação organizacional do poder eleitoral no México, Argentina, Costa Rica e Uruguai 


\section{SUMÁRIO}

INTRODUÇÃO

1 CONCEPÇÃO DO PROCESSO ELEITORAL NO BRASIL ............................. 19

1.1 Raízes do processo eleitoral no Brasil Colonial ............................................. 19

1.2 O processo eleitoral no Brasil Imperial ................................................................ 31

1.3 O processo eleitoral nos primeiros anos da República brasileira ....................... 53

1.4 Coronelismo e as fraudes no processo eleitoral brasileiro................................. 62

2 CRIAÇÃO DA JUSTIÇA ELEITORAL NO BRASIL ..................................... 71

2.1 A Revolução de 1930 e a criação da Justiça Eleitoral ........................................ 71

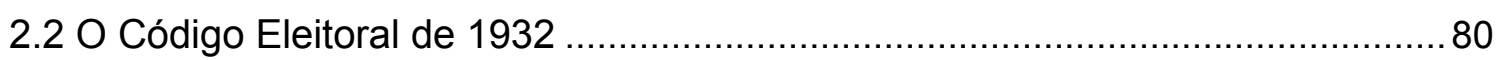

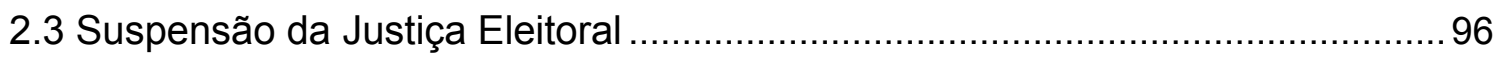

2.4 O retorno da Justiça Eleitoral na Constituição Federal de 1946 ........................ 100

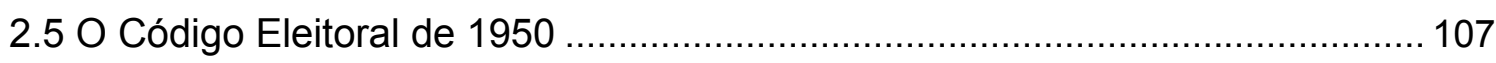

3 A CONSOLIDAÇÃO DA JUSTIÇA ELEITORAL ........................................ 117

3.1 A Ditadura Militar e a concepção do Código Eleitoral de 1965 ......................... 117

3.2 Os antecedentes da eleição de Tancredo Neves ........................................... 125

3.3 A Justiça Eleitoral e a Constituição Federal de 1988 ...................................... 132

3.3.1 Alguns princípios balizadores da Justiça Eleitoral .................................. 138

3.3.2 Os direitos políticos na Constituição Federal de 1988.............................. 149

3.3.3 Da organização da Justiça Eleitoral .................................................... 156

3.3.4 Competência da Justiça Eleitoral ........................................................ 161

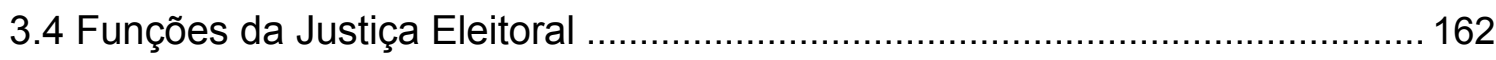

3.4.1 A função administrativa.............................................................. 164

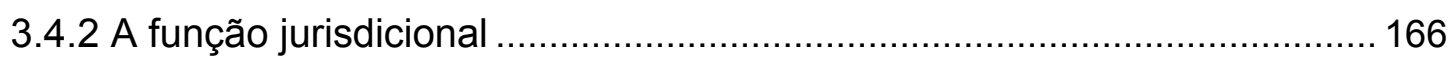

3.4.3 A função consultiva ...................................................................... 168

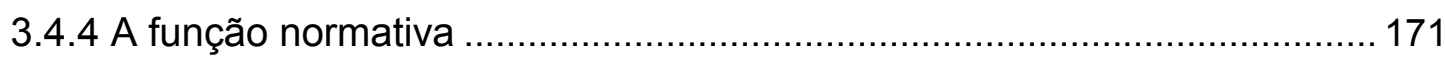

4 A EXPANSÃO DA JUSTIÇA ELEITORAL ............................................. 177

4.1 A verticalização das coligações eleitorais ..................................................... 177

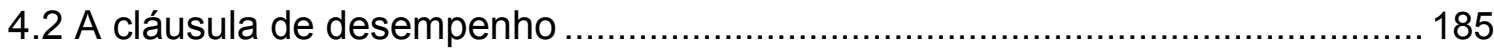

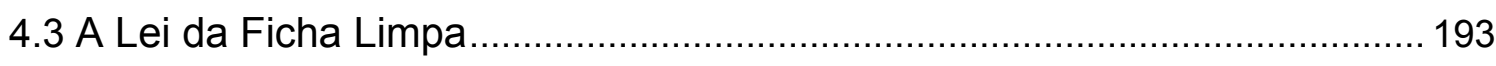

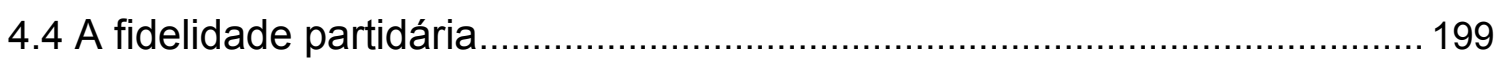


5 UMA BREVE ANÁLISE COMPARADA DOS SISTEMAS ELEITORAIS DA AMÉRICA LATINA: MÉXICO, COSTA RICA, ARGENTINA E URUGUAI....207

5.1 México

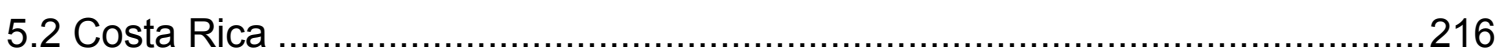

5.3 Argentina.

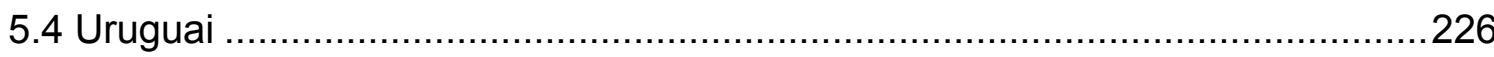

5.5 Um olhar comparado entre as nações........................................................229

CONCLUSÃO

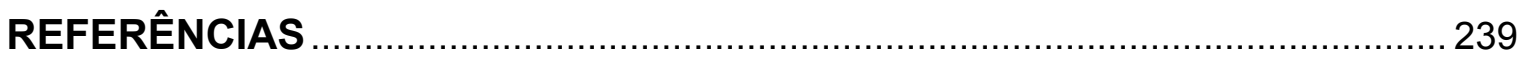




\section{INTRODUÇÃO}

A Justiça Eleitoral no Brasil destaca-se pelo seu histórico repleto de fases e transformações que culminaram na instituição como a conhecemos nos dias atuais. Todavia um processo eleitoral per se não está condicionado à existência de uma Justiça Eleitoral, uma vez que, muito antes de seu surgimento, mais precisamente no ano de 1932, já existia no país um processo eleitoral em pleno funcionamento.

Contudo, tal procedimento carecia de método e retidão, desvirtuando-se totalmente do ideal de processo eleitoral, em virtude da falta de segurança e da supressão de direitos e garantias dos cidadãos. Como exemplo dos excessos cometidos, Nelson Jobim sintetiza que, por volta de meados do século XIX, "somente aqueles que financiavam os gastos do Estado poderiam votar"1. O voto restringia-se a um seleto grupo da sociedade (as elites), sendo, por via de consequência, proibido para as pessoas de baixa renda, analfabetos e mulheres.

Justamente, em face desse caótico sistema eleitoral, restou imperiosa a necessidade de criação de uma Justiça Eleitoral, para nortear os caminhos da sedimentação do Estado Democrático de Direito. Pode-se dizer que a Justiça Eleitoral auxiliou no florescimento da democracia em nosso país, tornando-se, por conseguinte, um importante instrumento para sua manutenção ao longo dos anos.

No entanto, sua implantação e desenvolvimento em solo nacional não aconteceram de forma rápida, tampouco ascendente. Na verdade, a instabilidade política vivida em nosso país até 1985 dá mostras de que a estabilização da democracia foi uma tarefa árdua e demorada. Assim, a evolução da Justiça Eleitoral se deu de forma não linear e os eventos que envolvem o desenvolvimento de tal instituição não podem ser analisados sob uma perspectiva de continuidade, sem considerar os avanços e retrocessos existentes ao longo da história política do país.

A falta de linearidade na evolução histórica da Justiça Eleitoral é patente. A título de exemplo, basta mencionar que ela foi criada em 1932, suspensa em 1935 pela Lei de Segurança Nacional, e extinta em 1937, pela Constituição do Estado

\footnotetext{
${ }^{1} \mathrm{JOBIM}$, Nelson. Brasil, uma pincelada no sistema eleitoral. In: NORONHA, João Otávio de; KIM, Richard Pae (Coord.). Sistema político e direito eleitoral brasileiros: estudos em homenagem ao Ministro Dias Toffoli. Prefácio Ministro Carlos Ayres Britto. São Paulo: Atlas, 2016. p. 606.
} 
Novo, voltando à ativa de forma embrionária, somente no ano de 1945 , por força da Lei Agamenon, sendo devidamente legitimada pela Constituição de 1946, com o fim do período autoritário comandado por Getúlio Vargas.

Além desses eventos, têm-se ainda os retrocessos existentes durante o período mais obscuro da história política do país, qual seja, a instauração do regime militar em 31 de março de 1964.

Não obstante a Justiça Eleitoral ter avançado incrivelmente do ponto de vista jurídico, garantindo que os ideais basilares de democracia fossem aprioristicamente cumpridos, sua atuação ainda carece de aperfeiçoamento para que, por intermédio de instrumentos jurídicos válidos, os problemas oriundos de nossa delicada estrutura política sejam sanados.

Esta dissertação se propõe a analisar a importância da criação e a efetividade da Justiça Eleitoral para a garantia da legalidade, da legitimidade e da transparência do processo eleitoral brasileiro, refletindo sobre a forma e as prerrogativas pelas quais ela foi criada e se desenvolveu.

Trata-se de um estudo de fundamental relevância, uma vez que a garantia da integridade do processo eleitoral é imprescindível para a manutenção da democracia. Além disso, é imperioso ressaltar que a atuação da Justiça Eleitoral de maneira transparente e progressista é condição sine qua non para a consolidação de um regime democrático de qualidade.

Neste trabalho, demonstrar-se-á como os órgãos da Justiça Eleitoral aperfeiçoaram suas decisões em contextos de democracia e ditadura, tratando especialmente de suas funções e da expansão das mesmas, com o advento da Constituição da República Federativa do Brasil de 1988. Por fim, discute-se as tendências atuais para o órgão de fiscalização e administração do processo eleitoral, em sua fase de consolidação e expansão.

Esse panorama geral da atuação da Justiça Eleitoral será analisado por meio de casos paradigmáticos (leading cases), decididos pelo Tribunal Superior Eleitoral (TSE), e por meio de seus diálogos institucionais com o Supremo Tribunal Federal.

Ademais, investigar-se-á a forma de atuação dos órgãos da Justiça Eleitoral, em especial o TSE, nos períodos democráticos e, também, nos regimes ditatoriais 
vividos pelo povo brasileiro, em especial a ditadura militar, para então focar na fase transicional de restituição da democracia.

A jurisprudência do TSE será analisada em busca de uma compreensão mais plena sobre a interpretação da Corte Superior Eleitoral a respeito de aspectos polêmicos envolvendo temas como Ficha Limpa, cláusula de desempenho e fidelidade partidária.

Outro ponto de especial destaque a ser estudado no presente trabalho, diz respeito à necessidade de autonomia da Justiça Eleitoral para a garantia de maior efetividade e transparência na condução do processo eleitoral, bem como na apreciação de seus pontos contenciosos. Tal análise será realizada por intermédio de um estudo comparado entre sistemas eleitorais do México, Costa Rica, Argentina e Uruguai.

A presente pesquisa se baseou no método dedutivo, com detida análise da doutrina e da jurisprudência pertinentes à matéria e de obras produzidas por autores de notável saber jurídico, que foram utilizadas para fundamentar os argumentos e as conclusões levantados ao longo do trabalho. Artigos em revistas e periódicos científicos também foram utilizados para a construção do pensamento, em busca do aperfeiçoamento do saber jurídico.

Para a consecução dos objetivos propostos, o presente trabalho encontrase estruturado em cinco capítulos. O primeiro destina-se ao estudo das raízes do processo eleitoral no Brasil, desde o período colonial até os primeiros anos da república.

Nesse capítulo, destaca-se o período conhecido como "Velha República", marcado pelo domínio dos grandes latifundiários sobre a estrutura política e social, e pelo "voto de cabresto", alcunha derivada diretamente da manipulação dos eleitores, por parte dos coronéis, para a eleição de pessoas de acordo com seus interesses.

Conforme será explicado, uma das características marcantes dos primeiros anos da República é a existência e manutenção da cultura do coronelismo ${ }^{2}$, pela

\footnotetext{
${ }^{2}$ Nesse sentido, Vitor Nunes Leal e Raymundo Faoro dissertam sobre as raízes do coronelismo no Brasil, analisando sua estrutura, nas respectivas obras "Coronelismo, enxada e voto" (LEAL, Victor Nunes. Coronelismo, enxada e voto: o município e o regime representativo no Brasil. 7. ed. São Paulo: Companhia das Letras, 2012) e "Os donos do poder" (FAORO, Raymundo. Os donos do poder: formação do patronato político brasileiro. 4. ed. São Paulo: Globo, 2012).
} 
qual, os "coronéis" estabeleciam uma prática socialmente aceita e contumaz de subjugar o povo com ameaças e intimidações, criando assim um regime de submissão hierárquica, no qual a manipulação política era uma das práticas mais recorrentes ${ }^{3}$.

No segundo capítulo, serão abordados aspectos referentes à criação da Justiça Eleitoral no Brasil, que teve como marco contextual a Revolução de 1930, com foco nos principais obstáculos que provocaram oscilações em seu processo evolutivo, tais como sua suspensão na Era Vargas e seu restabelecimento com a "Nova Constituição" no ano de 1946.

No terceiro capítulo, demonstrar-se-á de que forma a Justiça Eleitoral se consolidou no país, detalhando sua manutenção e adaptação durante o regime militar e sua plena ascensão no período turvo, entre o fim da ditadura e o retorno da democracia, em especial nos momentos que antecederam a vitória de Tancredo Neves. Neste capítulo, faz-se ainda uma análise da Justiça Eleitoral após a Constituição Federal de 1988, diploma de maior importância na história recente do Direito brasileiro e fundamental para a consolidação da Justiça Eleitoral no país.

O quarto capítulo destina-se ao estudo da Justiça Eleitoral em sua configuração atual, dentro do processo de consolidação da democracia e frente ao instável cenário político nacional. Temas controversos que estão, ou estiveram, em debate na doutrina e jurisprudência serão objeto de investigação. Começando pela verticalização das coligações eleitorais, passando pela cláusula de barreira, o julgamento da Lei da Ficha Limpa e a fidelidade partidária e seu regramento instrumentos jurídicos e legislativos utilizados e legitimados pela Justiça Eleitoral para a manutenção da democracia.

Por fim, o quinto e último capítulo dedica-se a um estudo comparado do impacto e dos benefícios da implantação da Justiça Eleitoral e de órgãos de controle nos seguintes países da América Latina: México, Costa Rica, Argentina e Uruguai.

Referido estudo é enriquecedor e necessário para o presente trabalho, pois permite uma cuidadosa visualização dos pontos convergentes entre os sistemas jurisdicionais latino-americanos e, em especial, dos aspectos divergentes de sua

\footnotetext{
${ }^{3}$ Para a plena efetivação desse tipo de burla à verdade eleitoral, existiam os mecanismos de fraudes conhecidos popularmente como "degola" e "bico de pena".
} 
aplicação (ou não), demonstrando, por conseguinte, a importância da criação da Justiça Eleitoral ou de órgãos de controle para a proteção das garantias mais basilares da democracia.

O presente estudo se reveste de extrema importância para a discussão sobre a efetividade da Justiça Eleitoral na manutenção do Estado Democrático de Direito, visto que a produção acadêmica nacional na área não é tão vasta, sobretudo, quando se consideram aspectos importantes como a não linearidade da história da Justiça Eleitoral e sua atuação em períodos de níveis diferentes de democracia, ou ainda, de asfixia da mesma.

Certo é que o advento da institucionalização da Justiça Eleitoral teve o intuito de "fazer frente à necessidade de as eleições serem conduzidas em ambiente neutro, sem a contaminação daqueles que a disputam"4, com o claro objetivo de garantir uma democracia de qualidade.

Contudo, não se imaginava que a Justiça Eleitoral, desde a sua criação, pudesse ser tão testada e posta à prova, sobretudo em períodos de extremo autoritarismo, e ainda assim subsistir e chegar ao século XXI com nova roupagem, ganhando um protagonismo ainda maior no atual estágio da democracia brasileira, frente aos problemas diversos de nosso sistema político e eleitoral.

\footnotetext{
${ }^{4}$ SILVA, Henrique Neves da. Regulamentação eleitoral pelo Tribunal Superior Eleitoral. In: NORONHA, João Otávio de; KIM, Richard Pae (Coord.). Sistema político e direito eleitoral brasileiros: estudos em homenagem ao Ministro Dias Toffoli. Prefácio Ministro Carlos Ayres Britto. São Paulo: Atlas, 2016. p. 351.
} 


\section{CONCLUSÃO}

Em se tratando de Justiça Eleitoral, a história brasileira é demasiadamente rica, mas, ao mesmo tempo, controversa, uma vez que os períodos em que o Brasil gozou de plena estabilidade política são efêmeros. Em verdade, vários foram os conflitos políticos e ideológicos experimentados ao longo dos anos, o que, inequivocamente, atrasou os avanços nacionais para a estabilização da democracia.

Para que um Estado seja considerado verdadeiramente democrático, não basta apenas que sejam realizadas as eleições proforma. Existem determinados requisitos que devem ser cumpridos, sem os quais o processo eleitoral torna-se viciado e previsível. Obviamente as eleições são imprescindíveis à manutenção da democracia, contudo, atualmente no Brasil, deve-se pensar na qualidade democrática, que se aperfeiçoa por meio da existência de normas que regulem o jogo político, mas que não determinem o resultado, que sempre deve ser imprevisível.

Dessa forma conforme indicado na introdução deste trabalho, amparada pelos ideais de consolidação e manutenção da democracia e visando a regular o jogo político, a Justiça Eleitoral passou por diversas transformações ao longo de sua história. E não poderia ser diferente, pois, mesmo antes do surgimento da justiça especializada, existia no Brasil um embrionário processo eleitoral, ainda deficiente para a sedimentação da democracia, mas, suficiente para a criação e difusão da Justiça Eleitoral nos moldes como a conhecemos nos dias atuais.

O debate sobre o papel da Justiça Eleitoral é absolutamente necessário para demonstrar que ao longo de sua existência ela tem evoluído e se transformado, na tentativa de combater todas as formas de deturpações que, infelizmente, surgem e ressurgem no cenário político nacional.

Um momento de crucial demonstração de sua força e evolução está associado à evidente tensão existente entre democracia e autoritarismo, tema extensamente debatido ao longo de toda a pesquisa. Os momentos obscuros foram vários e, muitas vezes, chegaram sem aviso prévio, demonstrando a vulnerabilidade do ordenamento jurídico eleitoral brasileiro. Assim, diante da 
instável história política brasileira, adveio a necessidade de se analisar, profundamente, a criação e a atuação da Justiça Eleitoral no processo eleitoral nacional.

Em períodos sombrios vivenciados pelo Brasil, o processo eleitoral, que deveria ter sido empregado para a manutenção do Estado Democrático de Direito, não cumpriu seu efetivo papel, tendo sido, por vezes, contraditório ao legitimar ações completamente contrárias à democracia. Tome-se como exemplo a Era Vargas e o período em que vigorou o regime militar, dois contextos amplamente debatidos ao longo do trabalho.

Contudo, com o tempo, a Justiça Eleitoral ganhou folego e se mostrou muito mais presente na defesa da democracia. Frise-se, inclusive, que mesmo durante o autoritarismo, candidatos contrários ao regime foram eleitos e empossados, o que demonstra a autoridade de uma Justiça Eleitoral bem estabelecida. Além disso, os Códigos Eleitorais de 1935, 1945, 1950 e 1965 foram elaborados por membros do próprio judiciário eleitoral, em clara demonstração de que, não obstante as instituições democráticas estarem abaladas, a Justiça Eleitoral perdurou, na medida do possível, com sua atuação judicial para a manutenção da democracia.

Dessa forma o objetivo do presente trabalho, em suma, foi analisar e determinar, de maneira diacrônica, a importância da criação da Justiça Eleitoral para a evolução e a manutenção da democracia no Brasil, evidenciando aspectos de sua atuação nos mais variados cenários políticos experimentados pela nação, bem como avaliando como o seu desempenho e evolução influenciaram no desenvolvimento e enriquecimento das instituições democráticas brasileiras.

Referido estudo é crucial para o aperfeiçoamento da Justiça Eleitoral, dada a constante instabilidade política vivenciada em nosso país, que, por vezes, dificultou e mesmo tentou aplacar a atuação da Justiça Eleitoral brasileira.

Apesar de ser possível decompor a história eleitoral brasileira a ponto de organizá-la didaticamente entre esses dois extremos (democracia e ditadura), é possível sentir interferências externas que arriscaram, e ainda arriscam, deturpar a verdade eleitoral vinda das urnas. Mesmo nos períodos do Brasil democrático é possível identificar resquícios de autoritarismo, assim como, por outro lado, o espírito democrático nunca foi totalmente reprimido, ainda que em épocas de ditadura. 
Nesse sentido, torna-se imperiosa a análise de como a Justiça Eleitoral tentou a todo custo salvaguardar a aplicação dos princípios democráticos em sua atuação. Para tanto, primou-se no presente estudo, pela realização de um mapeamento histórico da criação da Justiça Eleitoral, com o objetivo de analisar detidamente seu campo de atuação e seu desenvolvimento como órgão garantidor do Estado Democrático de Direito.

Confirma-se, portanto, as suspeitas delimitadas nas hipóteses iniciais, principalmente aquela que diz respeito à importância da atuação da Justiça Eleitoral, que extirpou velhas deturpações existentes no processo eleitoral, em especial as tentativas de interferir no voto, prática comum no início da instituição da democracia no país.

A atuação dos órgãos da Justiça Eleitoral, que começou de forma tímida, muito atrelada aos interesses dos governantes, está cada vez mais rígida e forte. O grau de seriedade com que as matérias eleitorais são tratadas demonstra o comprometimento do TSE e dos demais órgãos da Justiça Eleitoral para com a democracia.

Apesar disso, se antes eram verificados vícios explícitos, como o "voto de cabresto", hoje os vícios cometidos são mais sofisticados, como é o caso do abuso do poder econômico, que exige uma correta hermenêutica para que não se proceda a uma violação da vontade sufragada nas urnas.

Ante o exposto e após a análise comparada com outros países da América Latina, que apresentam um histórico cultural similar ao do Brasil, a conclusão a que se chega é a de que de que os vícios, no processo eleitoral, ainda subsistem, mesmo que de forma implícita, razão pela qual a manutenção da democracia exige um maior aperfeiçoamento dos organismos que fiscalizam e administram o processo eleitoral.

Não obstante, os referidos vícios podem e devem ser contornados e coibidos de forma muito mais ativa pela Justiça Eleitoral, que cada vez mais, deve ganhar autonomia plena para a sua atuação, do mesmo modo que as consolidadas democracias latino-americanas, como Costa Rica e Uruguai.

No Brasil, a Justiça Eleitoral, ainda permanece vinculada ao Poder Judiciário; porém, o fato de não estar subordinada aos poderes Executivo e Legislativo lhe garante uma autonomia muito mais significativa em sua atuação. 
Destaque-se ainda que é perceptível a movimentação de seus membros para a realização de acordos de troca de informações e de estudos comparados, e para uma ativa participação em eventos mundiais com temas que tratam do aperfeiçoamento da democracia e da Justiça Eleitoral, o que demonstra que se busca atualmente um aprimoramento do órgão no exercício de suas funções.

Conforme exposto ao longo do trabalho, a atuação mais ativa da Justiça Eleitoral é desejável até mesmo em razão de suas competências. São vários os assuntos de sua responsabilidade, demandando muitas vezes uma postura mais fluida dos seus membros perante as necessidades do caso concreto.

Nesse sentido, inclusive, dois são os principais pontos de atenção a serem destacados. Primeiro, a nossa estrutura organizacional, que merece a mesma preocupação demonstrada pelos mexicanos de revisão das inúmeras funções atribuídas à Justiça Eleitoral - o acúmulo de funções pode comprometer a qualidade da fiscalização e da administração do processo eleitoral. O segundo ponto de atenção trata da segurança jurídica, uma vez que a Justiça Eleitoral não pode incorrer em decisões arbitrárias, possibilidade que surge quando se dá abertura para a atuação ativista, fora de suas competências originárias.

As derradeiras conclusões são mais específicas e dizem respeito aos problemas mais sofisticados relacionados à expansão da atuação da Justiça Eleitoral, como é o caso da cláusula de barreira, que se constitui como instituto controverso, recentemente reinserido no Direito brasileiro; matéria ainda nebulosa para os estudiosos. Para conhecer os seus reais efeitos no contexto atual da democracia é necessário paciência, a fim de que o instituto floresça e que seus efeitos possam ser avaliados do ponto de vista da jurisprudência e da doutrina.

A Lei da Ficha Limpa, por sua vez, representa um esforço da Justiça Eleitoral para conferir mais moralidade aos pleitos eleitorais, objetivo este que existe desde seus primórdios e ratifica o papel e a evolução da Justiça Eleitoral como guardiã do processo eleitoral democrático.

Outro ponto de especial destaque, que está intimamente ligado à conclusão sobre a necessidade de se desenvolver a autonomia plena da Justiça Eleitoral, é a obrigatoriedade de uma maior especialização dos magistrados eleitorais, considerando a criação de uma magistratura própria para os juízes singulares, os membros dos TRE, chegando até ao TSE, a fim de se evitar a todo o custo decisões 
rasas que sedimentam uma jurisprudência deficiente e, por conseguinte, trazem insegurança jurídica e atrasam o aperfeiçoamento da democracia no país.

Por fim, conclui-se que a Justiça Eleitoral está no caminho certo, sua relativa autonomia em relação aos demais poderes do Estado (permanece vinculada ao Poder Judiciário) e a identificação de ações que visam ao aprimoramento do órgão no país demonstram que a Justiça Eleitoral tem se mantido firme em exercer suas funções e em proteger, onde Ihe cabe, o Estado Democrático de Direito.

Esta conclusão é ratificada pela jurisprudência colacionada ao longo do trabalho, na qual se nota uma clara evolução na atuação do TSE e dos demais órgãos da Justiça Eleitoral frente aos abusos cometidos no campo eleitoral. Não é por outro motivo que estamos experimentando um período relativamente estável de democracia no país. As instituições parecem estar, cada vez mais, comprometidas com a realização do projeto democrático.

Regular o processo eleitoral no Brasil, terceira maior democracia do mundo, perdendo apenas para a Índia e para os Estados Unidos, não é tarefa fácil. As regras do jogo político estão em constante alteração - e precisam passar por transformações, para atender aos anseios da população e às novas configurações sociais. A população cresceu, a tecnologia se expandiu, a internet surgiu e com ela as redes sociais. Cabe à Justiça Eleitoral regular o processo eleitoral corretamente em cada contexto, para cada vez mais garantir a transparência e a confiança dos cidadãos brasileiros em suas instituições democráticas.

Fica evidente que a tarefa da Justiça Eleitoral é árdua. A história nos revela que o caminho em busca de uma democracia de qualidade é penoso e repleto de perigos. Qualquer desvio pode levar em direção ao autoritarismo e a outras deturpações nocivas à democracia.

O fortalecimento do Ministério Público Eleitoral, as cooperações técnicas com outros órgãos - como os tribunais de contas dos estados e da União e a Advocacia Geral da União -, os acordos para a troca de experiências com órgãos de gestão eleitoral de outros países, bem como a participação ativa da sociedade civil formam uma espécie de bastião de respeito aos princípios e regras que concretizam o princípio democrático e à preservação, cada vez mais almejada, da verdade eleitoral. 
Por fim, é imperioso destacar que a Justiça Eleitoral age conforme as leis afetas à matéria, ou seja, faz o que pode ser feito. Para se caminhar na direção de um processo eleitoral mais justo, é preciso que sejam positivadas normas fundantes, e não paliativas, debatidas e oriundas do seio da sociedade, que anseia por uma reforma política profunda e não simplesmente eleitoreira. 


\section{REFERÊNCIAS}

ABREU, Alzira Alves de. Partido Comunista do Brasil (PCB) [Verbete]. Fundação Getúlio Vargas-FGV CPDOC. Disponível em: $<$ http://www.fgv.br/cpdoc/acervo/dicionarios/verbete-tematico/partido-comunistado-brasil-pc-do-b>. Acesso em: 22 nov. 2017.

AGRA, Walber de Moura. Manual prático de direito eleitoral. Belo Horizonte: Fórum, 2016.

. Prismas do direito eleitoral: 80 anos do Tribunal Eleitoral de Pernambuco. Belo Horizonte: Fórum, 2012.

; VELLOSO, Carlos Mário da Silva. Elementos de direito eleitoral. 4. ed. São Paulo: Saraiva, 2014.

AIETA, Vânia Siciliano. Democracia: estudos em homenagem ao Prof. Siqueira Castro. Rio de Janeiro: Lúmen Juris, 2006. (Coleção Tratado de Direito Político; v. 2).

ALMEIDA, Fernando Menezes. Estatuto do candidato: reflexões sobre a "Lei Ficha Limpa". In: CAGGIANO, Monica Herman S. (Coord.). Direito eleitoral em debate: estudos em homenagem a Cláudio Lembo. São Paulo: Saraiva, 2013.

ALMEIDA NETO, Manoel Carlos de. Direito eleitoral regulador. 1. ed. São Paulo: Revista dos Tribunais, 2014.

AMARAL, Nemo de Andrade. Coronelismo, enxada e voto o município e o regime representativo no Brasil (1889-1930): uma visão crítica sobre a obra de Vitor Nunes Leal. 2004. Dissertação (Licenciatura) - Centro Universitário de Brasília, Brasília, $2004 . \quad$ Repositorio.Uniceub. Disponível em: <http://www.rcaap.pt/detail.jsp?id=oai:agregador.ibict.br.RI_UNICEUB:oai:localhos t:123456789/3504>. Acesso em: 15 set. 2017.

ARAÚJO, Luiz Alberto David. Formas de participação popular na gestão da coisa pública. In: MENDES, Gilmar Ferreira; MARTINS, Ives Gandra da Silva; TAVARES, André Ramos (Coords.). Lições de direito constitucional: em homenagem ao jurista Celso Bastos. São Paulo: Saraiva, 2005.

ARAÚJO, Maria Paula; SANTOS, Desirree dos Reis; SILVA, Izabel Pimentel da. Ditadura militar e democracia no Brasil: história, imagem e testemunho. 1. ed. Rio de Janeiro: Ponteio, 2013. 
ARAÚJO, Washington Luís Bezerra de. O voto no Brasil: da colônia ao império. Fortaleza: Escola Superior da Magistratura do Ceará; Escola Judiciária Eleitoral, 2007.

ARGENTINA. Competencia de la Cámara Nacional Electoral. Disponível em: <https://www.electoral.gob.ar/nuevo/paginas/cne/competencia_cne.php>. Acesso em 29 abr. 2018.

Dirección Nacional Electoral - DINE. Disponível em: <https://www.argentina.gob.ar/elecciones2017/dine>. Acesso em: 04 maio 2018.

AROCENA, José. Sistema electoral de Uruguay. In: SEMINÁRIO SOBRE AS REFORMAS ELEITORAIS NA AMÉRICA LATINA. [2016?], Buenos Aires. Disponível em: <https://275rzy1ul4252pt1hv2dqyuf-wpengine.netdna-ssl.com/wpcontent/uploads/2016/06/SISTEMA-ELECTORAL-DEL-URUGUAY.doc>. Acesso em: 01 maio 2018.

ÁVILA, Humberto. Teoria dos princípios: da definição à aplicação dos princípios jurídicos. 15. ed. rev e atual. São Paulo: Malheiros Ed., 2014.

AZAMBUJA, Darcy. Teoria geral do Estado. 4. ed. rev. e atual. São Paulo: Globo, 2008.

AZEVEDO, Alexandre Francisco de. Governança eleitoral: uma comparação entre os modelos de justiça eleitoral no Brasil e na Argentina. 2015. 114 f. Dissertação (Mestrado) - Programa de Pós-Graduação Stricto Sensu em Direito da PUC - Goiás, Goiânia, 2015.104 p. Disponível em: <http://tede2.pucgoias.edu.br:8080/bitstream/tede/2760/1/ALEXANDRE\%20FRAN CISCO\%20DE\%20AZEVEDO.pdf>. Acesso em: 30 abr. 2018.

BALEEIRO, Aliomar. O Supremo Tribunal Federal, esse outro desconhecido. 1. ed. Rio de Janeiro: Forense, 1968.

BANDEIRA DE MELLO, Celso Antônio. Curso de direito administrativo. 32. ed. São Paulo: Malheiros Ed., 2015.

BARBOSA, Paula Bezerra. Avanços na tecnologia desenvolvida pela Justiça Eleitoral no Brasil e seus efeitos na contemporaneidade. Estudos Eleitorais, v. 9, n. 3, p. 91-115, set./dez. 2014. Disponível em: <http://www.egov.ufsc.br/portal/sites/default/files/avancos_na_tecnologia_desenvo Ivida_pela_justica_eleitoral_no_brasil_e_seus_efeitos_na_contemporaneidade.pdf >. Acesso em: 05 out. 2017. 
BARREIROS NETO, Jaime. Histórico do processo eleitoral brasileiro e retrospectiva das eleições. Portal de e-governo, inclusão digital e sociedade do conhecimento - UFSC, Florianópolis, 2012. Disponível em: <http://www.egov.ufsc.br/portal/conteudo/historico-do-processo-eleitoral-brasileiroe-retrospectiva-das-eleicoes>. Acesso em: 15 set. 2017.

BARROSO, Luís Roberto. Curso de direito constitucional contemporâneo: os conceitos fundamentais e a construção do novo modelo. 4. ed. São Paulo: Saraiva, 2013.

BASBAUM, Leôncio. História sincera da República. 4. ed. São Paulo: Alfa-Ômega, 1976. v. 2.

BAZAGA, Rochelle Gutierrez. As "Diretas Já": uma análise sobre o impacto da campanha no processo de transição política brasileira. In: SIMPÓSIO NACIONAL DE HISTÓRIA, ANPUH, 27., 2013, Natal. Anais... - ANPUH. Natal: ANPUH, 2013. p. 1-11. Disponível em: <http://www.snh2013.anpuh.org/resources/anais/27/1364952315_ARQUIVO_ART IGOANPUH_1_.pdf>. Acesso em: 07 nov. 2017.

BERNARDO, Clarissa Campos; BAHIA, Cláudio José Amaral. Breve ensaio acerca da (in) fidelidade partidária. In: COSTA, Wagner, L. G; PETRONIO, Calmon (Orgs.). Direito eleitoral: estudos em homenagem ao Desembargador Mathias Coltro. 1. ed. Brasília: Gazeta Jurídica, 2014. v. 1.

BERNARDO, Raul. Repúdio ao voto distrital. Política, n. 6, p. 19-21, out./dez. 1977.

BETANZOS TORRES, Yasmín et al. (Comp.). ¿Qué es Tribunal Electoral del Poder Judicial de la Federación? 2. ed. México: Tribunal Electoral del Poder Judicial de la Federación e Agência Española de Cooperación Internacional para el Desarrollo, 2014. Disponível em: <http://portal.te.gob.mx/sites/default/files/que_es_el_tepjf_2014.pdf>. Acesso em: 26 abr. 2018.

BISPO, Isis Carolina Garcia; SILVA, Marcos. A inquisição ibérica como instituição responsável pela cristalização do mito de pureza de sangue no corpo social da américa portuguesa. In: SIMPÓSIO INTERNACIONAL DE ESTUDOS INQUISITORIAIS, Salvador, ago. 2011. Disponível em: $<$ http://www3.ufrb.edu.br/simposioinquisicao/wpcontent/uploads/2012/01/\%C3\%8Dsis-Bispo.pdf>.

BOMFIM, Manoel. O Brasil Nação. Rio de janeiro: Record, 1998.

BONAVIDES, Paulo. Ciência política. 17. ed. São Paulo: Malheiros Ed., 2010. 
NO BRASIL, parlamentarismo vigorou durante o Império e após renúncia de Jânio Quadros. Portal de Notícias do Senado, 13 ago. 2010. Disponível em: <https://www.senado.gov.br/noticias/Especiais/eleicoes2010/historia/no-brasilparlamentarismo-vigorou-durante-o-imperio-e-apos-renuncia-de-janioquadros.aspx>. Acesso em: 2 nov. 2017

BRASIL. Tribunal Superior Eleitoral. Eleições no Brasil: uma história de 500 anos. Pesquisa histórica e elaboração de textos: Ane Ferrari Ramos Cajado, Thiago Dornelles, Amanda Camylla Pereira. Brasília: Tribunal Superior Eleitoral, 2014. Disponível em: <http://www.tse.jus.br/hotsites/catalogo-publicacoes/pdf/tseeleicoes-no-brasil-uma-historia-de-500-anos-2014.pdf>.

. Tribunal Superior Eleitoral. Títulos eleitorais: 1881-2008. Brasília: Tribunal Superior Eleitoral, Secretaria de Gestão da Informação, 2009. (Série apontamentos; n. 2). Disponível em: <http://www.tse.jus.br/hotsites/catalogopublicacoes/pdf/titulos_eleitorais/Titulos_Eleitorais_1881_2008.pdf>. Acesso em: 30 out. 2017.

BUENO, Newton Paulo. A Revolução de 1930: uma sugestão de interpretação baseada na nova economia institucional. Revista Estudos Econômicos, São Paulo, v. $37, \quad$ n. 2 , p. 435-455, abr./jun. 2007. Disponível em: <http://www.scielo.br/pdf/ee/v37n2/08.pdf>. Acesso em: 27 set. 2017.

CAGGIANO, Monica Herman S. Coligações partidárias: verticalizar ou nãoverticalizar. Portal de e-governo, inclusão digital e sociedade do conhecimento. Disponível em: <http://www.egov.ufsc.br/portal/sites/default/files/67671-89100-1pb.pdf>. Acesso em: 16 mar. 2018.

CANCELAMENTO de registro do Partido Comunista Brasileiro. Tribunal Superior Eleitoral. Disponível em: <http://www.tse.jus.br/jurisprudencia/julgadoshistoricos/cancelamento-de-registro-do-partido-comunista-brasileiro>. Acesso em: 23 nov. 2017.

CÂNDIDO, Joel J. Direito eleitoral brasileiro. 15. ed. rev. e atual. São Paulo: Edipro, 2012.

CANOTILHO, J J Gomes. Direito constitucional e teoria da Constituição. 7. ed. Coimbra: Almedina, 2003.

CARVAJAL PÉREZ, Marvin. O Tribunal Constitucional da Costa Rica. Revista da Faculdade de Direito, Universidade de São Paulo, São Paulo, v. 91, p. 201-219, jan. 1996. ISSN 2318-8235. Disponível em: <https://www.revistas.usp.br/rfdusp/article/view/67335>. Acesso em: 28 abr. 2018. 
CARVALHO, José Murilo de. Mandonismo, coronelismo e clientelismo: uma discussão conceitual. Dados, Rio de Janeiro, v. 40, n. 2, 1997. Disponível em: $<$ http://www.scielo.br/scielo.php?script=sci_arttext\&pid=S0011$52581997000200003>$. Acesso em: 15 set. 2017.

CASTELLO Branco sancionava há 48 anos Código Eleitoral em plena ditadura. Migalhas, 15 jul. $2013 . \quad$ Disponível em: $<$ http://www.migalhas.com.br/Quentes/17,Ml182481,61044-

Castello+Branco+sancionava+ha+48+anos+Codigo+Eleitoral+em+plena>. Acesso em: 21 nov. 2017.

CERQUEIRA, Thales Tácito Pontes Luz de Pádua. "Ficha limpa" \& questões constitucionais: "Direito Eleitoral do Inimigo" (retroagir?). Estudos Eleitorais, Brasília, TSE, v. 5, n. 1, p. 65-75, jan./abr. 2010. Disponível em: $<$ http://bibliotecadigital.tse.jus.br/xmlui/handle/bdtse/417>.

; CERQUEIRA, Camila Medeiros de Albuquerque Pontes Luz de Pádua; INFANTE, Cristiane de O. Parisi. Tratado de direito eleitoral: direito material eleitoral: parte I. São Paulo: Premier Máxima, 2008. t. 1.

CLÁUSULA de barreira. Senado Notícias. Disponível em: <https://www12.senado.leg.br/noticias/glossario-legislativo/clausula-de-barreira>. Acesso em: $21 \mathrm{fev} .2018$.

COELHO, Marcus Vinicius Furtado. Direito eleitoral e processo eleitoral: direito penal eleitoral e direito político. 3. ed. rev. e atual. Rio de Janeiro: Renovar, 2012.

COELHO, Margarete de Castro. Sobre o envolvimento de instituições judiciais em disputas políticas: o papel da Justiça Eleitoral brasileira. In: DIREITO eleitoral: debates Ibero-americanos. Memórias do $\mathrm{V}$ Congresso Ibero-americano de Direito Eleitoral e do IV Congresso de Ciência Política e Direito Eleitoral do Piauí. Compiladores: Ana Claudia Santano, Eneida Desiree Salgado. Curitiba: Ithala, 2014. p. 15-24.

COMPARATO, Fábio Konder. Para viver a democracia. São Paulo: Brasiliense, 1989.

CORONELISMO e Direito Eleitoral na Velha República. GT X - Direito e Desenvolvimento. In: SEMINÁRIO DE PESQUISA DO CCSA. CIDADANIA EM TEMPOS DE TOLERÃNCIA, 21., UFRN, 2-6 maio 2016. Disponível em: $<$ https://seminario2016.ccsa.ufrn.br/assets//upload/papers/6f4dd68b9b76bd52936 89a754b861c43.pdf>. Acesso em: 16 set. 2017. 
COSTA, Rafael Antônio. O poder de polícia do Juiz Eleitoral. Eleitoral Brasil, 28 abr. 2016. Disponível em: <http://www.eleitoralbrasil.com.br/noticias/o-poder-de-policiado-juiz-eleitoral>. Acesso em: 13 nov. 2017.

COULANGES, Fustel de. A Cidade Antiga. Tradução de Frederico Ozanam Pessoa de Barros. São Paulo: Ed. das Américas, 2006.

DAHL, Robert A. Sobre a democracia. Tradução de Beatriz Sidou. Brasília: Ed. da Universidade de Brasília, 2001.

. Sobre a democracia. Brasília: Ed. da Universidade de Brasília, 2009.

DALLA VIA, Alberto Ricardo. Organización de la Justicia Electoral Argentina y control judicial. 09 dez. 2010. 17. Slides. Material apresentado no Seminario de Derechos Políticos en el Sistema Interamericano de Derechos Humanos - TEPJF (México). Disponível em: <http://www.te.gob.mx/ccje/Archivos/dalla_organizacion.pdf>. Acesso em: 30 abr. 2018.

DALLARI, Dalmo de Abreu. Elementos de teoria geral do Estado. 32. ed. São Paulo: Saraiva, 2015.

. O pequeno exército paulista. São Paulo: Perspectiva, 1977.

DEFESA do Partido Comunista do Brasil. Disponível em: <http://www.tse.jus.br/hotSites/registro_partidario/pcb/arquivos/defesa_partido.pdf >. Acesso em: 23 nov. 2017.

DIAS, Rodrigo Francisco. Tancredo Neves e a redemocratização do Brasil. Temporalidades: Revista Discente do Programa de Pós-Graduação em História da UFMG, Belo Horizonte, v. 7, n. 3, set./dez. 2015. Disponível em: <https://seer.ufmg.br/index.php/temporalidades/article/viewFile/3375/2563>.

Acesso em: 06 nov. 2017.

DI PIETRO, Maria Sylvia Zanella. Direito administrativo. 19. ed. São Paulo: Atlas, 2006.

DUVERGER, Maurice. Os partidos políticos. Rio de Janeiro: Zahar, 1970.

EBERLE, Edward J. The method and role of comparative law. 8 Washington University Global Studies Law Review, Washington, n. 451, p. 455-469, 2009. Disponível em: <https://openscholarship.wustl.edu/law_globalstudies/vol8/iss3/2/>. Acesso em: 30 abr. 2018. 
ESPÍNDOLA, Ruy Samuel. TSE desrespeita a democracia representativa. Consultor Jurídico, São Paulo, 28 mar. 2012. Disponível em: $<$ https://www.conjur.com.br/2012-mar-28/aprovacao-contas-eleitorais-abusopoder-regulamentar-tse>. Acesso em: 12 abr. 2018.

FAORO, Raymundo. Os donos do poder: formação do patronato político brasileiro. 4. ed. São Paulo: Globo, 2012.

FARIAS, Adriana Silva de; IGNATZ, Mariana Schafer. Partidos políticos e princípio da fidelidade partidária. Disponível em: <http://ufrr.br/direito/index.php?option=com_phocadownload\&view=category\&dow nload=156: partidos-politicos-e-principio-da-fidelidade-partidaria-autoras-adrianasilva-de-farias-mariana-schafer-ignatz-orientador-prof-msc-jose-edival-valebraga >. Acesso em: 20 fev. 2018.

FAUSTO, Boris. História do Brasil. 14. ed. rev. e atual. São Paulo: Ed. da Universidade de São Paulo; Fundação do Desenvolvimento da Educação, 2015.

. A revolução de 1930: historiografia e história. São Paulo: Companhia das Letras, 1997.

FENELON, Priscila Primo. A democracia na Argentina e no Brasil: fatores econômicos e cultura política. 2016. 89 f. Monografia (Bacharel em Ciências Sociais) - Instituto de Filosofia e Ciências Humana da UFRGS, Porto Alegre, 2016.

FERRARO, A. R. Educação, classe, gênero e voto no Brasil imperial: Lei Saraiva 1881. Educar em Revista, Curitiba, n. 50, p. 181-206, out./dez. 2013. Disponível em: <http://www.scielo.br/pdf/er/n50/n50a12.pdf>. Acesso em: 28 ago. 2017.

FERREIRA, Manoel Rodrigues. A evolução do sistema eleitoral brasileiro. 2. ed. rev. e atual. Brasília: Tribunal Superior Eleitoral, 2005.

FERREIRA, Pinto. Código Eleitoral comentado. 4. ed. ampl. e atual. São Paulo: Saraiva, 1997.

FERREIRA FILHO, Manoel Gonçalves. Aspectos do direito constitucional contemporâneo. 3. ed. São Paulo: Saraiva, 2011.

FIORI, José Luis. O poder global: e a nova geopolítica das nações. São Paulo: Boitempo Editorial, 2007.

FONSECA, Pedro Cezar Dutra. A gênese regional da "revolução de 30". Revista Estudos Econômicos, São Paulo, v. 29, n. 1, p. 113-127, 1999. Disponível em: <https://www.revistas.usp.br/ee/article/view/117213>. Acesso em: 27 set. 2017. 
FORJAZ, Maria Cecília Spina. Tenentismo [Verbete]. Fundação Getúlio VargasFGV CPDOC. Disponível em: $<$ http://cpdoc.fgv.br/sites/default/files/verbetes/primeirarepublica/TENENTISMO.pdf>. Acesso em: 29 set. 2017.

FUX, Luiz. Princípios do direito eleitoral. In: NORONHA, João Otávio de; KIM, Richard Pae (Coords.). Sistema político e direito eleitoral brasileiros: estudos em homenagem ao Ministro Dias Toffoli. Prefácio Ministro Carlos Ayres Britto. São Paulo: Atlas, 2016.

GADELHA, Paulo. Do voto distrital. Revista de Informação Legislativa, Brasília, ano 24 , n. 94 , p. 249-252, abr./jun. 1987. Disponível em: $<$ https://www2.senado.leg.br/bdsf/bitstream/handle/id/181759/000431266.pdf?seq uence=3>. Acesso em: 20 ago. 2017.

GALLARDO, Alfonso Myers. A reforma política no México: uma análise crítica dos avanços e retrocessos nas novas leis eleitorais do país. Paraná Eleitoral, v. 3, n. 2, p. 1-31 Disponível em: <http://www.researchgate.net/profile/Alfonso_MyersGallardo/publication/273898415_A_reforma_poltica_no_Mxico_uma_anlise_crtica _dos_avanos_e_retrocessos_>. Acesso em: 29 abr. 2018.

GAMA NETO, Ricardo Borges. A legislação eleitoral de 1945 e suas consequências políticas. Revista Textos e Debates, Roraima, UFRR, 1995. Disponível em: <https://revista.ufrr.br/textosedebates/article/viewFile/907/748>. Acesso em: 20 out. 2017.

GHIGGI, Luciana. Legislação eleitoral e sistema político-partidário de 1945 a 1964: continuidades e rupturas. 2014. Dissertação (Mestrado em Ciência Política) Universidade Federal do Rio Grande do Sul, Porto Alegre, 2014. Disponível em: <http://www.lume.ufrgs.br/bitstream/handle/10183/116463/000964180.pdf?sequen $\mathrm{ce}=1>$. Acesso em: 30 out. 2017.

GILMAR Mendes diz que STF errou em decisão sobre cláusula de barreira. Câmara Notícias, 212017.2 Dar. 21 isponível <http://www2.camara.leg.br/camaranoticias/noticias/POLITICA/526598-GILMARMENDES-DIZ-QUE-STF-ERROU-EM-DECISAO-SOBRE-CLAUSULA-DEBARREIRA.html>. Acesso em: 24 fev. 2018.

GLOSSÁRIO eleitoral brasileiro [Capacidade eleitoral]. Tribunal Superior Eleitoral. Disponível em: <http://www.tse.jus.br/eleitor-e-eleicoes>. Acesso em: 24 fev. 2018.

GOMES, José Jairo. Direito eleitoral. 13. ed. rev. e atual. São Paulo: Atlas, 2017. 
GONÇALVES, Luiz Carlos dos Santos. Direito eleitoral. 2. ed. São Paulo: Atlas, 2012.

GONZAGA NETO, Admar. Fidelidade partidária e sua nova versão segundo a minirreforma eleitoral. In: CARVALHO NETO, Tarcisio Vieira de; FERREORA, Telson Luís Cavalcante (Coords.). Direito eleitoral: aspectos processuais e materiais. São Paulo: Migalhas, 2016.

GONZÁLES ROURA, Felipe. Sistema de justicia electoral en la Argentina. In: SEMINÁRIO INTERNACIONAL SOBRE SISTEMAS DE JUSTICIA ELECTORAL: EVALUACIÓN Y PERSPECTIVAS, 1999, México. Anais... México: IFE; PNUD; UNAM; Ilj; IFES; IDEA Internacional; TEPJF, 2001. p. 251-274. Disponível em: $<$ http://www.te.gob.mx/documentacion/publicaciones/libros/sistemas.pdf>. Acesso em: 29 abr. 2018.

GORDILHO, Pedro. A justiça eleitoral e o processo de redemocratização (reminiscência de um advogado-juiz). Conferência pronunciada no I Congresso de Advogados do Estado da Bahia, a convite da Ordem dos Advogados do Brasil, em 28 de outubro de 1982. Boletim Eleitoral, Brasília, ano 32, n. 385, p. 57-63, ago. 1983.

GRAU, Eros Roberto. Por que tenho medo dos juízes (a interpretação/aplicação do direito e os princípios). 6. ed. São Paulo: Malheiros Ed., 2014.

GROS ESPIELL, Héctor. La Corte Electoral del Uruguay. San José: Instituto Interamericano de Derechos Humanos; Centro de Asesoría y Promoción Electoral - IDH - CAPEL, 1990.

A HISTÓRIA da luta pelo direito de voto das mulheres... Discurso pronunciado pelo Dep. Lincoln Portela (PSL-MG, na Sessão de / /02). Portal Brasil, Seção Governo, 18 nov. 2009. Disponível em: <www.camara.gov.br/sileg/integras/50093.doc>. Acesso em: 9 nov. 2017.

HOLANDA, S. B. de (Dir.). Do Império à República. 2. ed. São Paulo: Difel, 1977. (Coleção História geral da civilização brasileira; tomo II - O Brasil monárquico, v. 5).

INSTITUTO NACIONAL ELECTORAL. Reforma Constitucional 2014. Disponível em: <https://www.ine.mx/sobre-el-ine/reforma-constitucional-2014/>. Acesso em: 28 abr. 2018.

Servicio Profesional Electoral Nacional. Disponível em: <http://sitios.ine.mx/archivos3/portal/historico/contenido/interiores/Menu_Principalid-DESPEN_Que_es/>. Acesso em: 26 abr. 2018. 
INSTITUTO NACIONAL ELECTORAL. V Foro de la Democracia Latinoamericana: Tribunal Electoral del Poder Judicial de la Federación. Disponível em: <http://portalanterior.ine.mx/archivos3/portal/historico/contenido/interiores/Menu_P rincipal-id-V_Foro_Democracia/>. Acesso em: 27 abr. 2018.

JEHÁ, Pedro Rubez. Aspectos jurídicos do financiamento eleitoral no Brasil. In: CAGGIANO, Monica Herman S. (Coord.). Direito Eleitoral em debate: estudos em homenagem a Cláudio Lembo. São Paulo: Saraiva, 2013.

JOBIM, Nelson. Brasil, uma pincelada no sistema eleitoral. In: NORONHA, João Otávio de; KIM, Richard Pae (Coord.). Sistema político e direito eleitoral brasileiros: estudos em homenagem ao Ministro Dias Toffoli. Prefácio Ministro Carlos Ayres Britto. São Paulo: Atlas, 2016.

JUSTIÇA eleitoral do Brasil, 80 anos - O voto feminino no Brasil. Brasília-DF, Tribunal Superior Eleitoral, [200-]. Disponível em: <http://www.tse.jus.br/arquivos/tre-sp-o-voto-feminino-pdf>. Acesso em: 09 nov. 2017.

KINZO, Maria D'Alva G. A democratização brasileira: um balanço do processo político desde a transição. São Paulo em Perspectiva, Revista da Fundação Seade, São Paulo, v. 15, n. 4, p. 3-12, dez. 2001. Disponível em: <http://www.seade.gov.br/wp-content/uploads/2014/07/v15n4.pdf>. Acesso em: 07 nov. 2017.

LAURELL, Asa Cristina. A democracia no México: o primeiro será o último? Lua Nova, São Paulo, n. 24, p. 217-254, set. 1991. Disponível em: <http://www.scielo.br/scielo.php?script=sci_arttext\&pid=S010264451991000200012\&lng=en\&nrm=iso>. Acesso em: 27 abr. 2018.

LEAL, Victor Nunes. Coronelismo, enxada e voto: o município e o regime representativo no Brasil. 7. ed. São Paulo: Companhia das Letras, 2012.

LEÃO, Michele. Lei Saraiva (1881): se o analfabetismo é um problema, exclui-se o problema. Aedos: Revista do Corpo Discente do Programa de Pós-Graduação em História da UFRGS, Rio Grande do Sul, v. 4, n. 11, p. 602-615, 2012. Disponível em: <http://seer.ufrgs.br/index.php/aedos/article/view/30737/20890>. Acesso em: 27 ago. 2017.

LEMBO, Cláudio; CAGGIANO, Monica Herman S. Direitos políticos: o partido político, canal de comunicação entre governante e governados. In: MARTINS, Ives Gandra da Silva; MENDES, Gilmar Ferreira; NASCIMENTO, Carlos Valder (Coords.). Tratado de direito constitucional. 2. ed. São Paulo: Saraiva, 2012. v. 1. 
LEVINE, Daniel H; MOLINA, José Enrique. Notas sobre la calidad de la democracia en América Latina: índice específico y evaluación comparada de los países. Revista América Latina de Hoy da Universidade de Salamanca, Salamanca, n. 45, p. 1746, abr. 2007.

LEWANDOWSKI, Enrique Ricardo. Breves considerações sobre a Reforma Política em discussão no Congresso Nacional. In: CAGGIANO, Monica Herman S. (Coord.). Direito eleitoral em debate: estudos em homenagem a Cláudio Lembo. São Paulo: Saraiva, 2013.

. Colapso do populismo e regime militar no Brasil. Revista da Faculdade de Direito da Universidade de São Paulo, São Paulo, v. 93, p. 229-245, 1998. Disponível em: <https://www.revistas.usp.br/rfdusp/article/view/67404/70014>. Acesso em: 27 fev. 2018.

Direito comunitário e soberania: algumas reflexões. Revista da Faculdade de Direito da Universidade de São Paulo, São Paulo, v. 92, p. 231-242, jan. 1997. Disponível em: <http://www.revistas.usp.br/rfdusp/article/view/67362>. Acesso em: 27 fev. 2018.

A formação da doutrina dos direitos fundamentais. In: In: MENDES, Gilmar Ferreira; MARTINS, Ives Gandra da Silva; TAVARES, André Ramos. (Coords.). Lições de direito constitucional: em homenagem ao jurista Celso Bastos. São Paulo: Saraiva, 2005.

- Pressupostos materiais e formais da intervenção federal no Brasil. São Paulo: Revista dos Tribunais, 1994.

Reflexões em torno do princípio republicano. Revista da Faculdade de Direito da Universidade de São Paulo, São Paulo, v. 100, p. 189-200, jan. 2005. Disponível em: <https://www.revistas.usp.br/rfdusp/article/view/67670/70278>. Acesso em: 01 mar. 2018.

LIMA, Martonio Mont' Alverne Barreto; LIMA, Renal Saldanha de Paula. Resquícios do coronelismo no processo político-eleitoral do século XXI. Revista Culturas Jurídicas, Rio de Janeiro, v. 3, n. 6, p. 98-127, 2016. Disponível em: <http://www.culturasjuridicas.uff.br/index.php/rcj/article/download/183/102>.

Acesso em: 14 set. 2017.

LOPES, Fláucia do Prado Fonseca. A justiça eleitoral no Brasil: evolução do sistema eleitoral, da colônia ao voto eletrônico. Brasília: Universidade de Legislativo Brasileiro, 2008. 
LOPES, Raimundo Hélio. O Poder Discricionário: o Governo Provisório nas páginas do jornal carioca Correio da Manhã (1930-1932). In: SIMPÓSIO NACIONAL DE HISTÓRIA - ANPUH, 29., 2017, São Paulo. Anais... São Paulo: USP, 2017. Disponível em: <http://www.snh2017.anpuh.org/resources/anais/54/1488719551_ARQUIVO_texto completoanpuh2017RaimundoHLopes.pdf>. Acesso em: 16 set. 2017.

LUCON, Paulo Henrique dos Santos; VIGLIAR, José Marcelo Menezes. Código eleitoral interpretado: normas eleitorais complementares. 3. ed. São Paulo: Atlas, 2013.

MALUF, Nagiba Maria Rizék. Revolução de 32: o que foi: por que foi. 2. ed. São Paulo: Global, 2009.

A MÁQUINA de votar no Código Eleitoral de 1932. Memorial da Justiça Eleitoral Gaúcha. Porto Alegre, Tribunal Regional Eleitoral do Rio Grande do Sul, 2016. Disponível em: $<$ http://www.trers.jus.br/arquivos/A_maquina_de_votar_no_Codigo_Eleitoral_de_1932_Programa _de_09092016.pdf>. Acesso em: 7 out. 2017.

MARTINS, Ives Gandra da Silva. A nova Legislação Eleitoral. [Seção de Debates]. In: PARTIDOS e sistemas eleitorais em tempos de reforma. São Paulo: Fundação Konrad Adenauer, 1995. p. 87-109. (Debates, n. 9). Disponível em: <https://pt.scribd.com/document/61718394/ADENAUER-Deb-9-Partidos-eSistemas-Eleitorais-Em-Tempos-de-Reforma>. Acesso em: 16 set. 2017.

- Parlamentarismo e presidencialismo. In: COÊLHO, Marcus Vinicius Furtado; AGRA, Walber de Moura (Coords.). Direito eleitoral e democracia: desafios e perspectivas. Brasília: Conselho Federal da OAB, 2010.

MAXIMILIANO, Carlos. Hermenêutica e aplicação do direito. 5. ed. Rio de Janeiro: Freitas Bastos, 1951.

MENDES, Gilmar Ferreira. Jurisdição constitucional: o controle abstrato de normas no Brasil e na Alemanha. 6. ed. São Paulo: Saraiva, 2014.

Reforma eleitoral: perspectivas atuais. In: NORONHA, João Otávio de; KIM, Richard Pae (Coords.). Sistema político e direito eleitoral brasileiros: estudos em homenagem ao Ministro Dias Toffoli. Prefácio Ministro Carlos Ayres Britto. São Paulo: Atlas, 2016.

; BRANCO, Paulo Gustavo Gonet. Curso de direito constitucional. 9. ed. rev. e atual. São Paulo: Saraiva, 2014. 
MENDES, Gilmar Ferreira; MARTINS, Ives Gandra da Silva; TAVARES, André Ramos (Coords.). Lições de direito constitucional: em homenagem ao jurista Celso Bastos. São Paulo: Saraiva, 2005.

MENDONÇA, Daniel de. A vitória de Tancredo Neves no Colégio Eleitoral e a posição política dos semanários Veja e Isto É. Alceu (PUCRJ), Rio de Janeiro, v. 5, n. 10, p. 164-185, jan./jun. 2005. Disponível em: <http://revistaalceu.com.pucrio.br/media/alceu_n10_mendonca.pdf>. Acesso em: 06 nov.2017.

MENEGUELLO, Rachel. Nota preliminar para um estudo da Justiça Eleitoral. In: SADEK, Maria Tereza (Org.). Eleições 1986. São Paulo: IDESP, 1989.

MEZAROBBA, Glenda. Entre reparações, meias verdades e impunidade: o difícil rompimento com o legado da ditadura no Brasil. Revista internacional de Direitos Humanos-SUR, São Paulo, v. 7, n. 13, p. 7-25, dez. 2010.

MEZZAROBA, Orides. Introdução ao direito partidário brasileiro. Rio de Janeiro: Lùmen Juris, 2002.

MIRANDA, Francisco Cavalcanti Pontes de. Comentários à Constituição de 1946. 2. ed. rev. ampl. Rio de Janeiro: Max Limonad, 1953.

MIRANDA, Jorge. Manual de direito constitucional: estrutura constitucional da democracia. Portugal: Coimbra Ed., 2007. t. 7.

MORAES, Alexandre de. Direito constitucional. 13. ed. São Paulo: Atlas, 2003. Direito constitucional. 26. ed. São Paulo: Atlas, 2010.

MOREIRA, Regina da Luz. Revolução Constitucionalista de 1932. Fundação Getúlio Vargas-FGV CPDOC. Disponível em: <http://cpdoc.fgv.br/producao/dossies/FatosImagens/Revolucao1932>. Acesso em: 06 dez. 2017.

MUSEU do Voto. Igreja e Eleições no Império. Brasília-DF: Tribunal Superior Eleitoral (TSE), 2010. Disponível em: <http://www.tse.jus.br/o-tse/cultura-ehistoria/museu-do-voto/temas/igreja-e-eleicoes-no-imperio>. Acesso em: 13 maio 2017.

NASPOLINI, Samuel Dal-Farra. Pluralismo político: subsídios para análise dos sistemas partidário e eleitoral brasileiros em face da Constituição Federal. Curitiba: Juruá, 2006.

NICOLAU, Jairo. Eleições no Brasil: do império aos dias atuais. Rio de Janeiro: Zahar, 2012. 
NICOLAU, Jairo. A reforma da representação proporcional no Brasil. In: BENEVIDES, Maria; VANNUCHI, Paulo; KERCHE, Fábio (Orgs.). Reforma política e cidadania. São Paulo: Fundação Perseu Abramo, 2003.

NOBRE JÚNIOR, Edilson Pereira. Justiça eleitoral: organização e competência. Disponível em: <http://www.egov.ufsc.br/portal/sites/default/files/anexos/1865318654-1-PB.pdf>. Acesso em: 24 nov. 2017.

NOLETO, Mauro Almeida. Verticalização de coligações partidárias: jurisprudência e conjuntura. Paraná Eleitoral, n. 58, out. 2005. Disponível em: <http://www.justicaeleitoral.jus.br/arquivos/tre-pr-revista-parana-eleitoral-n0582005-mauro-almeida-noleto>. Acesso em: 20 fev. 2018.

80 ANOS de história: TSE anula eleição geral realizada em MT. Tribunal Regional Eleitoral de Mato Grosso, Imprensa, Notícias, 08 nov. 2012. Disponível em: <http://www.tre-mt.jus.br/imprensa/noticias-tre-mt/2012/Novembro/80-anos-dehistoria-tse-anula-eleicao-geral-realizada-em-mt>. Acesso em: 05 dez. 2017.

80 ANOS do voto feminino. Agência Câmara Notícias, Brasília, 24 fev. 2012. Disponível em: <http://www2.camara.leg.br/camaranoticias/noticias/POLITICA/409785-80-ANOSDO-VOTO-FEMININO.html>. Acesso em: 9 nov. 2017.

OLAVO, Luciano. Sufrágio, voto, escrutínio, plebiscito e referendo. Disponível em: <http://www.lucianoolavo.com.br/sufragio_plebiscito_referendo.html>. Acesso em: 31 out. 2017.

OLIVEIRA, Lúcia Lippi; VELLOSO, Mônica Pimenta; GOMES, Ângela Maria de Castro. Estado Novo: ideologia e poder. Rio de Janeiro: Zahar, 1982.

OLIVEIRA, Marcelo Roseno de. Controle das eleições: virtudes e vícios do modelo constitucional brasileiro. Belo Horizonte: Fórum, 2010.

ORIÁ, Ricardo. Mulher e cidadania: a conquista do voto feminino no Brasil. Cadernos ASLEGIS, n. 38, set./nov. 2009.

OVÍDIO, Francisco. Aspectos do direito comparado. Revista da Faculdade de Direito, Universidade de São Paulo, São Paulo, v. 79, p. 161-180, jan. 1984. Disponível em: <https://www.revistas.usp.br/rfdusp/article/view/67009>. Acesso em: 28 abr. 2018.

PAIM, Gustavo Bohrer. Direito eleitoral e segurança jurídica. Porto Alegre: Livr. do Advogado, 2016. 
PEREIRA, Erick Wilson. Direito eleitoral: interpretação e aplicação das normas constitucionais-eleitorais. São Paulo: Saraiva, 2010.

PÉREZ DUHARTE, José Alfredo. Comparación de experiencias sobre administración de elecciones y resolución de conflictos: los casos de Argentina, Costa Rica, México y Uruguay. Revista de Direito Eleitoral do Tribunal Supremo de Elecciones, Costa Rica, n. 18, p. 232-263, 2014. Disponível em: <http://www.tse.go.cr/revista/art/4/urruty_anexo.pdf>. Acesso em: 01 maio 2018.

PERÍODO republicano teve início em 1889, com a proclamação da República pelo Marechal Deodoro. Portal Brasil, Seção Governo, 18 nov. 2009. Disponível em: <http://www.brasil.gov.br/governo/2009/11/brasil-republica/>. Acesso em: 31 ago. 2017.

PIZZOLATTI, Rômulo. A competência da Justiça Eleitoral. Resenha Eleitoral: nova série. Florianópolis, . 5, n. 1, jan./jun. 1998. Disponível em: <http://www.tresc.jus.br/site/resenha-eleitoral/revista-tecnica/edicoesimpressas/integra/2012/06/a-competencia-da-justicaeleitoral/index047b.html?no_cache=1\&cHash=4f198f1dc5d67fe5cab1c93e6efedd 46>. Acesso em: 24 nov. 2017.

PLENÁRIO do STF considera "cláusula de barreira" inconstitucional. Notícias STF, 07 dez. $2006 . \quad$ Disponível em: <http://www.stf.jus.br/portal/cms/verNoticiaDetalhe.asp?idConteudo=68591>. Acesso em: 26 fev. 2018.

PORTO, Walter Costa. A mentirosa urna. São Paulo: Martins Fontes, 2004.

PORTUGAL. Ordenações Filipinas. In: JOBIM, Nelson; PORTO, Walter Costa (Orgs.). Legislação eleitoral no Brasil: do século XVI a nossos dias. Brasília: Senado Federal, Subsecretaria de Biblioteca, 1996. v. 1. Disponível em: $<$ http://www2.senado.leg.br/bdsf/bitstream/handle/id/224494/LEB_V1.pdf?sequenc $e=5>$.

PRADO JUNIOR, Caio. Evolução política do Brasil: colônia e império. São Paulo: Brasiliense, 1933.

PRIMEIRO Código Eleitoral do Brasil completa 81 anos. Tribunal Superior Eleitoral, Imprensa, Notícias, Brasília, 22 fev. 2013. Disponível em: <http://www.tse.jus.br/imprensa/noticias-tse/2013/Fevereiro/primeiro-codigoeleitoral-do-brasil-completa-81-anos>. Acesso em: 6 out. 2017. 
O PROCESSO eleitoral - O Senado e a primeira República. Assembleia Legislativa do Estado de São Paulo, 15 jul. 2002. Disponível em: <https://www.al.sp.gov.br/noticia/?id=292066>. Acesso em: 16 set. 2017.

PROGRAMA DAS NAÇÕES UNIDAS PARA O DESENVOLVIMENTO (PNUD); TRIBUNAL SUPERIOR ELEITORAL. Desafios para a democracia são tema de debate durante Reunião de Autoridades Eleitorais do Mercosul. Brasil, set. 2017. Centro de Notícias. Disponível: <http://www.br.undp.org/content/brazil/pt/home/presscenter/articles/2017/09/20/de safios-para-a-democracia-s-o-tema-de-debate-durante-reuni-o-de-autoridadeseleitorais-do-mercosul.html .

QUEIROZ, Luiz Viana. Lei da ficha limpa e respeito â coisa julgada. In: ROLLEMBERG, Gabriela; DIAS, Joelson; KUFA, Karina (Orgs.). Aspectos polêmicos e atuais no direito eleitoral. Belo Horizonte: Arraes Editores, 2012.

RAMAYANA, Marcos. Direito eleitoral. 5. ed. Niterói-RJ: Impetus, 2015.

RAMOS, Elival da Silva. Controle de constitucionalidade no Brasil: perspectivas da evolução. São Paulo: Saraiva, 2010.

RANIERI, Nina Beatriz Stocco. Teoria do Estado: do Estado de Direito ao Estado Democrático de Direito. São Paulo: Manoel, 2013.

REIS, Márlon Jacinto. O princípio constitucional da proteção e a definição legal das inelegibilidades. In: REIS, Márlon Jacinto; OLIVEIRA, Marcelo Roseno de; CASTRO, Edson de Resende (Coord.). Ficha Limpa: Lei Complementar $n^{\circ} 135$, de 4.6.2010: interpretada por juristas e responsáveis pela iniciativa popular. Bauru: Edipro, 2010.

RIBEIRAL, Tatiana Braz. Justiça eleitoral e direitos políticos no Brasil e no México. Cadernos Adenauer, São Paulo, v. 15, p. 261-275, set. 2014. Disponível em: <http://www.kas.de/wf/doc/13783-1442-5-30.pdf>. Acesso em: Acesso em: 6 out. 2017.

RIBEIRO, Fávila. Constituinte e participação popular. São Paulo: Saraiva, 1986. Direito eleitoral. Rio de Janeiro: Forense, 1988.

. Pressupostos constitucionais do direito eleitoral: no caminho da sociedade participativa. Porto Alegre: Fabris Editor, 1990. 
RICCI, Paolo; SILVA, Glauco Peres da. O Código Eleitoral de 1932 e a invenção da proporcional. In: ENCONTRO DA ASSOCIAÇÃO BRASILEIRA DE CIÊNCIA POLíTICA, 10., 2016, Belo Horizonte. Belo Horizonte, 2016. Disponível em: $<$ https://cienciapolitica.org.br/system/files/documentos/eventos/2017/04/codigoeleitoral-1932-e-invencao-proporcional-965.pdf>. Acesso em: 6 out. 2017.

ROCHA, Cármen Lúcia Antunes. Justiça Eleitoral e representação democrática. In: ROCHA, Cármen Lúcia Antunes; VELLOSO, Carlos Mário da Silva (Coords.). Direito eleitoral. Belo Horizonte: Del Rey, 1996.

RODRIGUES, Manoel Ferreira. A evolução do sistema eleitoral brasileiro. 2. ed. rev. e alt. Brasília-DF: TSE/SDI, 2005.

RODRIGUES, Marcelo Abelha; JORGE, Flávio Cheim. Manual de direito eleitoral. São Paulo: Revista dos Tribunais, 2014.

ROMANELLI, Otaiza de Oliveira. História da educação no Brasil. 27. ed. PetrópolisRJ: Vozes, 2002.

ROSAS, Suzana Cavani. A dança dos círculos. In: NEVES, Lúcia Maria Bastos Pereira das; FERREIRA, Tânia Maria Tavares Bessone da Cruz (Coords.). Dimensões políticas do Império do Brasil. Rio de Janeiro: Contra Capa, 2017.

RUI Barbosa. Discurso de 10 de julho de 1879. Brasília-DF: Câmara dos Deputados, 1985. (Perfis parlamentares; v. 28).

SADEK, Maria Tereza. A justiça eleitoral e a consolidação da democracia no Brasil. São Paulo: Konrad Adenauer, 1995.

SAIBA mais sobre o Brasil Império. Portal Brasil, Seção Governo e Política, 6 nov. 2009. Disponível em: <http://www.brasil.gov.br/governo/2009/11/imperio/>. Acesso em: 31 ago. 2017.

SALES, Campos. Da propaganda à Presidência. São Paulo: Typ. "A Editora", 1908.

SALGADO, Eneida Desiree. Princípios constitucionais eleitorais. Belo Horizonte: Fórum, 2015.

SAMPAIO JÚNIOR, José Herval. Organização da Justiça Eleitoral brasileira: os Tribunais. Disponível em: <https://joseherval.jusbrasil.com.br/artigos/162575153/organizacao-da-justicaeleitoral-brasileira-os-tribunais>. Acesso em: 25 nov. 2017

SARLET, Ingo Wolfgang; MARINONI. Luiz Guilherme; MITIDIERO. Daniel. Curso de direito constitucional. 3. ed. rev. e atual. São Paulo: Revista dos Tribunais, 2014. 
SARTORI, Giovanni. Engenharia constitucional. Tradução Sérgio Bath. Brasília: Ed. da Universidade de Brasília, 1996.

SCATIMBURGO, João de. O Poder Moderador. São Paulo: Livr. Pioneira, 1980.

SENADO aprova cláusula de barreira a partir de 2018 e fim de coligação para 2020. Senado Notícias, 03 out. 2017. Disponível em: <https://www12.senado.leg.br/noticias/materias/2017/10/03/aprovado-fim-dascoligacoes-em-eleicoes-proporcionais-a-partir-de-2020>. Acesso em: 24 fev. 2018.

SHIRADO, Nayana. A reeleição para um mandato subsequente no poder executivo municipal interpretada pelo Tribunal Superior Eleitoral: o adeus à candidaturaintinerante. Revista de Jurisprudência do Tribunal Regional Eleitoral do Amazonas, Manaus, n. 9, p. 55-89, 2008. Disponível em: <http://bibliotecadigital.tse.jus.br/xmlui/handle/bdtse/809>. Acesso: em 02 mar. 2018.

SIERRA, Gerónimo de. Democracia e modernização na transição uruguaia. Lua Nova, São Paulo, n. 16, p. 103-121, mar. 1989. Disponível em: <http://www.scielo.br/pdf/ln/n16/a05n16.pdf>. Acesso em: 04 maio 2018.

SILVA, Cecília de Almeida et al. Diálogos institucionais e ativismo. 1. ed. Curitiba: Juruá, 2012.

SILVA, Henrique Neves da. Regulamentação eleitoral pelo Tribunal Superior Eleitoral. In: NORONHA, João Otávio de; KIM, Richard Pae (Coord.). Sistema político e direito eleitoral brasileiros: estudos em homenagem ao Ministro Dias Toffoli. Prefácio Ministro Carlos Ayres Britto. São Paulo: Atlas, 2016.

SILVA, José Afonso da. O constitucionalismo brasileiro: evolução institucional. São Paulo: Malheiros Ed., 2011.

. Curso de direito constitucional positivo. 38. ed. rev. e atual. São Paulo: Malheiros Ed., 2015.

SILVA, Lyana Maria Martins da. Reforma gorada: a Lei do Terço e a representação das minorias nas eleições de 1876 em Pernambuco. 2014. Dissertação (Mestrado em História) - Programa de Pós-Graduação em História, da Universidade Federal de Pernambuco, Recife, 2014. Disponível em: <https://repositorio.ufpe.br/bitstream/123456789/11661/1/DISSERTA\%c3\%87\%c3 \%830\%20Lyana\%20Maria\%20Martins\%20da\%20Silva.pdf>. Acesso em: 28 abr. 2017. 
SILVA, Thiago; SILVA, Estevão. Eleições no Brasil antes da democracia: o Código Eleitoral de 1932 e os pleitos de 1933 e 1934. Revista de Sociologia Política, Curitiba, v. 23, n. 56, p. 75-106, dez. 2015. Disponível em: <http://www.scielo.br/scielo.php?script=sci_arttext\&pid=S010444782015000400075>. Acesso em: 05 out. 2017.

SILVEIRA, José Néri da. Aspectos do processo eleitoral. Porto Alegre: Livr. do Advogado, 1998.

SOARES, Marcos Antônio Striquer. Jurisdição e administração: duas funções da Justiça Eleitoral. Revista Jurídica da UniFil, Londrina, ano 3, n. 3, p. 114-121, 2005. Disponível em: <http://web.unifil.br/docs/juridica/03/Revista\%20Juridica_0312.pdf>. Acesso em: 11 nov. 2017.

SODRÉ, Nelson Werneck. História militar do Brasil. São Paulo: Expressão Popular, 2010.

SOUSA, José Virgílio Dias de. Aspectos gerais sobre a história do voto no Brasil. Ugopoci, Goiânia, 2010. Disponível em: <http://www.ugopoci.com.br/UserFiles/File/art_voto.pdf>. Acesso em: 05 nov. 2017.

SOUZA, Alexandre de Oliveira Bazilio de. Reformas eleitorais no final do Império: a reinvenção do cidadão brasileiro (1871-1889). In: SIMPÓSIO NACIONAL DE HISTÓRIA, ANPUH, 26., 2011, São Paulo. Anais... São Paulo, 2011. Disponível em:

<http://www.snh2011.anpuh.org/resources/anais/14/1312377523_ARQUIVO_Alex andredeOBaziliodeSouza.pdf>. Acesso em: 28 ago. 2017.

SOUZA, Felipe Azevedo e. A Lei Saraiva e o dever da cidadania. Documentação e Memória, TJPE, Recife, PE, v. 2, n.3, 73-93, jan./dez. 2010. Disponível em: <http://www.tjpe.jus.br/judiciario/didoc/Memorial/revista/revista032010/4_Felipe_A zevedo_e_Souza_A_Lei_Saraiva_e_o_Devir_da_Cidadania.pdf>. Acesso em: 27 ago. 2017.

STRECK, Lenio Luiz. Jurisdição constitucional e decisão jurídica. 4. ed. São Paulo: Revista dos Tribunais, 2014.

- Verdade e consenso: constituição, hermenêutica e teoria discursivas: da possibilidade à necessidade de respostas corretas em direito. 3. ed. Rio de Janeiro: Lúmen Juris, 2009.

TAVARES, Fernando Horta. Voto. In: DIMOULIS, Dimitri (Coord.). Dicionário brasileiro de direito constitucional. 2. ed. São Paulo: Saraiva, 2012. 
TAVARES, José Antônio Giusti. Sistemas eleitorais nas democracias contemporâneas: teoria, instituições, estratégia. Rio de Janeiro: Relume Dumará, 1994.

THEODORO JÚNIOR, Humberto. O parlamentarismo no Brasil. Revista da Faculdade de Direito da Universidade Federal de Minas Gerais, Belo Horizonte, n. 28-29, p. 187-210, 1986. Disponível em: <https://www.direito.ufmg.br/revista/index.php/revista/article/view/984>. Acesso em: 15 out. 2017.

TOCQUEVILLE, Alexis. A democracia na América. 2. ed. São Paulo: Ed. da Universidade de São Paulo, 1987.

TRIBUNAL SUPERIOR ELEITORAL. Memorando de Entendimento entre o TSE da República Federativa do Brasil e o Tribunal Eleitoral do Poder Judiciário da Federação do México para Cooperação Acadêmica e Científica em Matéria Eleitoral. Disponível: <http://english.tse.jus.br/arquivos/mexico-memoentendimento-versao-portugues>. Acesso em: 01 maio 2018.

TRIBUNAL SUPREMO DE ELECCIONES (REPÚBLICA DE COSTA RICA). ¿Qué es el TSE? - El Tribunal Supremo de Elecciones: una institución con múltiples funciones. Disponível em: <http://www.tse.go.cr/el_tse.htm>. Acesso em 27 abr. 2018.

URRUTY NAVATTA, Carlos Alberto. El Régimen Electoral Uruguayo. Revista de Direito Eleitoral do Tribunal Supremo de Elecciones, Costa Rica, n. 4, p. 1-13, 2007. Disponível em: <http://www.tse.go.cr/revista/art/4/urruty_anexo.pdf>. Acesso em: 01 maio 2018.

VALE, Teresa Cristina de Souza Cardoso. Aspectos históricos da Justiça Eleitoral brasileira. Cadernos Adenauer, São Paulo, v. 15, p. 11-25, set. 2014. <http://www.kas.de/wf/doc/13769-1442-5-30.pdf>. Acesso em: 26 set. 2017.

. Pré-história e história da Justiça Eleitoral. In: SIMPÓSIO NACIONAL DE HISTÓRIA, ANPUH, 26., 2011, São Paulo. Anais... São Paulo, 2011. Disponível em:

<http://www.snh2011.anpuh.org/resources/anais/14/1297170363_ARQUIVO_preh istoriaehistoraje.pdf>. Acesso em: 26 set. 2017.

VALLE, Álvaro. As novas estruturas políticas brasileiras. Rio de Janeiro: Nórdica, 1977. 
VALVERDE CAMIÑA, Vanessa. Definiendo modelos de administración electoral: el caso argentino a examen. Revista de Direito Eleitoral do Tribunal Supremo de Elecciones, Costa Rica, n. 11, p. 1-38, 2011. Disponível em: <http://www.tse.go.cr/revista/art/11/valverde_camina.pdf>. Acesso em: 01 maio 2018.

VARGAS, Jonas Moreira. A utilização de novas fontes documentais para o estudo das eleições e das facções políticas no Brasil Imperial. In: MOSTRA DE PESQUISA DO ARQUIVO PÚBLICO DO ESTADO DO RIO GRANDE DO SUL (4.: 2006: Porto Alegre/RS). Anais: produzindo história a partir das fontes primárias. Org. Marcia Medeiros da Rocha. Porto Alegre: CORAG, 2006.

VELLOSO, Carlos Mário da Silva. Elementos de direito eleitoral. 4. ed. São Paulo: Saraiva, 2014.

VIANA, Francisco José de Oliveira. Instituições políticas brasileira. Brasília-DF: Senado Federal, 1999.

VIVIANI, Fabrícia Carla. Tenentismo e modernização brasileira. Disponível em: <http://www.geocities.ws/politicausp/teoriapol/Modernidade/Viviani.pdf>. Acesso em: 05 dez. 2017.

\section{Legislação}

BRASIL. Carta de Lei de 25 de março de 1824. In: JOBIM, Nelson; PORTO, Walter Costa (Orgs.). Legislação eleitoral no Brasil: do século XVI a nossos dias. BrasíliaDF: Senado Federal, Subsecretaria de Biblioteca, 1996. v. 1. Disponível em: $<$ http://www2.senado.leg.br/bdsf/bitstream/handle/id/224494/LEB_V1.pdf?sequenc $e=5>$.

- Constituição (1988). Constituição da República Federativa do Brasil. Brasília-DF: $\quad$ Senado, $1988 . \quad$ Disponível em: <http://www.planalto.gov.br/ccivil_03/constituicao/constituicao.htm>. Acesso em: 17 mar. 2018.

Decreto 6.097, de 12 de janeiro de 1876. In: JOBIM, Nelson; PORTO, Walter Costa (Orgs.). Legislação eleitoral no Brasil: do século XVI a nossos dias. Brasília-DF: Senado Federal, Subsecretaria de Biblioteca, 1996. v. 1. Disponível em:

<http://www2.senado.leg.br/bdsf/bitstream/handle/id/224494/LEB_V1.pdf?sequenc $e=5>$. 
BRASIL. Decreto de 26 de março de 1824. In: JOBIM, Nelson; PORTO, Walter Costa (Orgs.). Legislação eleitoral no Brasil: do século XVI a nossos dias. BrasíliaDF: Senado Federal, Subsecretaria de Biblioteca, 1996. v. 1. Disponível em: $<$ http://www2.senado.leg.br/bdsf/bitstream/handle/id/224494/LEB_V1.pdf?sequenc $e=5>$.

Decreto de 29 de julho de 1828. In: JOBIM, Nelson; PORTO, Walter Costa (Orgs.). Legislação eleitoral no Brasil: do século XVI a nossos dias. Brasília-DF: Senado Federal, Subsecretaria de Biblioteca, 1996. v. 1. Disponível em: $<$ http://www2.senado.leg.br/bdsf/bitstream/handle/id/224494/LEB_V1.pdf?sequenc $e=5>$.

. Decreto de 7 de março de 1821. In: JOBIM, Nelson; PORTO, Walter Costa (Orgs.). Legislação eleitoral no Brasil: do século XVI a nossos dias. Brasília-DF: Senado Federal, Subsecretaria de Biblioteca, 1996. v. 1. Disponível em: $<$ http://www2.senado.leg.br/bdsf/bitstream/handle/id/224494/LEB_V1.pdf?sequenc $e=5>$.

. Decreto de 9 de agosto de 1827. In: JOBIM, Nelson; PORTO, Walter Costa (Orgs.). Legislação eleitoral no Brasil: do século XVI a nossos dias. Brasília-DF: Senado Federal, Subsecretaria de Biblioteca, 1996. v. 1. Disponível em: $<$ http://www2.senado.leg.br/bdsf/bitstream/handle/id/224494/LEB_V1.pdf?sequenc $e=5>$.

Decreto n. 1.082, de 18 de agosto de 1860. In: JOBIM, Nelson; PORTO, Walter Costa (Orgs.). Legislação eleitoral no Brasil: do século XVI a nossos dias. Brasília-DF: Senado Federal, Subsecretaria de Biblioteca, 1996. v. 1. Disponível em:

$<$ http://www2.senado.leg.br/bdsf/bitstream/handle/id/224494/LEB_V1.pdf?sequenc $e=5>$.

. Decreto n. 157, de 4 de maio de 1842. In: JOBIM, Nelson; PORTO, Walter Costa (Orgs.). Legislação eleitoral no Brasil: do século XVI a nossos dias. BrasíliaDF: Senado Federal, Subsecretaria de Biblioteca, 1996. v. 1. Disponível em: $<$ http://www2.senado.leg.br/bdsf/bitstream/handle/id/224494/LEB_V1.pdf?sequenc $e=5>$.

Decreto n. 2.675, de 20 de outubro de 1875. In: JOBIM, Nelson; PORTO, Walter Costa (Orgs.). Legislação eleitoral no Brasil: do século XVI a nossos dias. Brasília-DF: Senado Federal, Subsecretaria de Biblioteca, 1996. v. 1. Disponível em:

$<$ http://www2.senado.leg.br/bdsf/bitstream/handle/id/224494/LEB_V1.pdf?sequenc $e=5>$. 
BRASIL. Decreto n. 3.029, de 9 de janeiro de 1881. In: JOBIM, Nelson; PORTO, Walter Costa (Orgs.). Legislação eleitoral no Brasil: do século XVI a nossos dias. Brasília-DF: Senado Federal, Subsecretaria de Biblioteca, 1996. v. 1. Disponível em:

$<$ http://www2.senado.leg.br/bdsf/bitstream/handle/id/224494/LEB_V1.pdf?sequenc $e=5>$.

. Decreto n. 7586, de 28 de maio de 1945. In: JOBIM, Nelson; PORTO, Walter Costa (Orgs.). Legislação eleitoral no Brasil: do século XVI a nossos dias. Brasília-DF: Senado Federal, Subsecretaria de Biblioteca, 1996. v. 2. Disponível em:

$<$ http://www2.senado.leg.br/bdsf/bitstream/handle/id/224494/LEB_V2.pdf?sequenc $e=6>$.

Decreto n. 8.308, de 17 de novembro de 1881; Decreto n. 3.122, de 7 de outubro de 1882. In: JOBIM, Nelson; PORTO, Walter Costa (Orgs.). Legislação eleitoral no Brasil: do século XVI a nossos dias. Brasília-DF: Senado Federal, Subsecretaria de Biblioteca, 1996. v. 1. Disponível em: <http://www2.senado.leg.br/bdsf/bitstream/handle/id/224494/LEB_V1.pdf?sequenc $e=5>$.

Decreto n. 842, de 19 de setembro de 1855. In: JOBIM, Nelson; PORTO, Walter Costa (Orgs.). Legislação eleitoral no Brasil: do século XVI a nossos dias. Brasília-DF: Senado Federal, Subsecretaria de Biblioteca, 1996. v. 1. Disponível em:

$<$ http://www2.senado.leg.br/bdsf/bitstream/handle/id/224494/LEB_V1.pdf?sequenc $e=5>$.

. Emenda Constitucional n. 4, de 2 de setembro de 1961. In: JOBIM, Nelson; PORTO, Walter Costa (Orgs.). Legislação eleitoral no Brasil: do século XVI a nossos dias. Brasília-DF: Senado Federal, Subsecretaria de Biblioteca, 1996. v. 2. Disponível em: $<$ http://www2.senado.leg.br/bdsf/bitstream/handle/id/224494/LEB_V2.pdf?sequenc $\mathrm{e}=6>$.

Emenda Constitucional n. 6, de 23 de janeiro de 1963. In: JOBIM, Nelson; PORTO, Walter Costa (Orgs.). Legislação eleitoral no Brasil: do século XVI a nossos dias. Brasília-DF: Senado Federal, Subsecretaria de Biblioteca, 1996. v. 2. Disponível em: $<$ http://www2.senado.leg.br/bdsf/bitstream/handle/id/224494/LEB_V2.pdf?sequenc $\mathrm{e}=6>$. 
BRASIL. Lei de $1^{\circ}$ de outubro de 1828. In: JOBIM, Nelson; PORTO, Walter Costa (Orgs.). Legislação eleitoral no Brasil: do século XVI a nossos dias. Brasília-DF: Senado Federal, Subsecretaria de Biblioteca, 1996. v. 1. Disponível em: $<$ http://www2.senado.leg.br/bdsf/bitstream/handle/id/224494/LEB_V1.pdf?sequenc $\mathrm{e}=5>$.

Lei n. 1.164, de 24 de julho de 1950. In: JOBIM, Nelson; PORTO, Walter Costa (Orgs.). Legislação eleitoral no Brasil: do século XVI a nossos dias. BrasíliaDF: Senado Federal, Subsecretaria de Biblioteca, 1996. v. 2. Disponível em: $<$ http://www2.senado.leg.br/bdsf/bitstream/handle/id/224494/LEB_V2.pdf?sequenc $e=6>$.

. Lei n. 2.550, de 25 de julho de 1955. In: JOBIM, Nelson; PORTO, Walter Costa (Orgs.). Legislação eleitoral no Brasil: do século XVI a nossos dias. BrasíliaDF: Senado Federal, Subsecretaria de Biblioteca, 1996. v. 2. Disponível em: <http://www2.senado.leg.br/bdsf/bitstream/handle/id/224494/LEB_V2.pdf?sequenc $\mathrm{e}=6>$.

. Lei n. 2.982, de 30 de novembro de 1956. In: JOBIM, Nelson; PORTO, Walter Costa (Orgs.). Legislação eleitoral no Brasil: do século XVI a nossos dias. Brasília-DF: Senado Federal, Subsecretaria de Biblioteca, 1996. v. 2. Disponível em:

<http://www2.senado.leg.br/bdsf/bitstream/handle/id/224494/LEB_V2.pdf?sequenc $\mathrm{e}=6>$.

. Lei n. 387, de 19 de agosto de 1846. In: JOBIM, Nelson; PORTO, Walter Costa (Orgs.). Legislação eleitoral no Brasil: do século XVI a nossos dias. BrasíliaDF: Senado Federal, Subsecretaria de Biblioteca, 1996. v. 1. Disponível em: $<$ http://www2.senado.leg.br/bdsf/bitstream/handle/id/224494/LEB_V1.pdf?sequenc $\mathrm{e}=5>$.

Tribunal Regional Eleitoral do Rio de Janeiro. Código eleitoral comentado e legislação complementar. Rio de Janeiro: EJE/SAD/CADOC, 2012.

Tribunal Superior Eleitoral. Código eleitoral anotado e legislação complementar. 12. ed. Brasília: Tribunal Superior Eleitoral, Secretaria de Gestão da Informação, 2016. Disponível em: <http://www.tse.jus.br/hotsites/catalogopublicacoes/pdf/codigo_eleitoral/codigo-eleitoral-anotado-e-legislacaocomplementar-12-edicao-atualizado.pdf>. Acesso em: 11 nov. 2017.

Tribunal Superior Eleitoral. Código Eleitoral. Disponível em: <http://www.tse.jus.br/eleitor/glossario/termos/codigo-eleitoral>. Acesso em: 7 out. 2017. 
CABRAL, João C. da Rocha. Código Eleitoral da República dos Estados Unidos do Brasil: 1932. (Decreto n. 21.076, de fevereiro de 1932). Edição especial. Organizada a partir da obra fac-similar editada pelo TSE. Brasília-DF: Tribunal Superior Eleitoral, Subsecretaria de Documentação e Informação, 2004. Disponível em: $\quad<h t t p: / / w w w . t s e . j u s . b r / h o t s i t e s / c a t a l o g o-$ publicacoes/pdf/codigo_eleitoral_1932.pdf>. Acesso em: 7 out. 2017.

\section{Jurisprudência}

BOLETIM Eleitoral, Brasília, Tribunal Superior de Justiça Eleitoral, ano 10, n. 120, jul. $1961 . \quad$ Disponível em: <http://bibliotecadigital.tse.jus.br/xmlui/handle/bdtse/2177>. Acesso em: 06 jan. 2018.

, Brasília, Tribunal Superior de Justiça Eleitoral, ano 34, n. 402, jan. 1985. Disponível em: <http://bibliotecadigital.tse.jus.br/xmlui/handle/bdtse/1402>. Acesso em: 23 fev. 2018.

1932.

, Rio de Janeiro, Tribunal Superior de Justiça Eleitoral, ano 1, n. 2, 27 jul.

<http://bibliotecadigital.tse.jus.br/xmlui/bitstream/handle/bdtse/851/1932_boletim_e leitoral_a1_n2?sequence=1\&isAllowed=y>. Acesso em: 06 dez. 2017.

, Rio de Janeiro, Tribunal Superior de Justiça Eleitoral, ano 1, n. 5, ago. 1932. Disponível em: <http://bibliotecadigital.tse.jus.br/xmlui/handle/bdtse/854>. Acesso em: 05 jan. 2018.

, Rio de Janeiro, Tribunal Superior de Justiça Eleitoral, ano 1, n. 4, ago. 1932. Disponível em: <http://bibliotecadigital.tse.jus.br/xmlui/handle/bdtse/853>. Acesso em: 05 jan. 2018.

, Rio de Janeiro, Tribunal Superior de Justiça Eleitoral, ano 1, n. 6, 10 ago. 1932. Disponível em: <http://bibliotecadigital.tse.jus.br/xmlui/handle/bdtse/850>. Acesso em: 03 jan. 2018.

, Rio de Janeiro, Tribunal Superior de Justiça Eleitoral, ano 2, n. 13, 24 jan. 1933. 1934.

, Rio de Janeiro, Tribunal Superior de Justiça Eleitoral, ano 3, n. 2, 6 jan. 
BOLETIM Eleitoral, Rio de Janeiro, Tribunal Superior de Justiça Eleitoral, ano 1, n. 1, ago. $1951 . \quad 24 \quad$ p. $\quad$ Disponível em: <http://bibliotecadigital.tse.jus.br/xmlui/handle/bdtse/2010>. Acesso em: 05 jan. 2018.

, Rio de Janeiro, Tribunal Superior de Justiça Eleitoral, ano 1, n. 9, abr. 1952. 44 p. Disponível em: <http://bibliotecadigital.tse.jus.br/xmlui/handle/bdtse/1782>. Acesso em: 06 jan. 2018.

BRASIL. Supremo Tribunal Federal (STF). Ação Direta de Inconstitucionalidade $n$. 3.685-8. Requerente: Conselho Federal da Ordem dos Advogados Do Brasil. Requerido: Congresso Nacional. Relatora: Ministra Ellen Gracie, Brasília-DF. Disponível em: <http://www.stf.jus.br/imprensa/pdf/ADI3685\%20Eros\%20Grau.pdf>. Acesso em: 22 fev. 2018.

Supremo Tribunal Federal (STF). Ação Direta de Inconstitucionalidade $n$. 5081. Requerente: Procurador-Geral da República. Requerido: Tribunal Superior Eleitoral. Relator: Ministro Roberto Barroso. Brasília, 27 de maio de 2015. Disponível em: <http://portal.stf.jus.br/processos/detalhe.asp?incidente=4513055> Acesso em: 24 fev. 2018.

. Tribunal Superior Eleitoral (TSE). Agravo Regimental no Recurso Ordinário n. 499541. Agravante: Leonídio Henrique Correa Bouças. Agravado: Ministério Público Eleitoral. Relator: Ministro Aldir Passarinho Junior. Brasília, 26 de outubro de 2010.Disponivel em: <http://www.lexml.gov.br/urn/urn:lex:br:tribunal.superior.eleitoral;plenario:acordao; agr.ro:2010-10-26;ro-499541>. Acesso em: 24 fev. 2018.

Supremo Tribunal Federal (STF). A Constituição e o Supremo. RMS 23.123. Recorrente: Francisco de Assis Almeida e Silva. Recorrido: Tribunal Superior Eleitoral. Relator: Ministro Nelson Jobim. Brasília-DF, 12 março de 2004. Disponível em: <http://www.stf.jus.br/portal/constituicao/artigoBd.asp?item=1209>. Acesso em: 25 nov. 2017.

Tribunal Superior Eleitoral (TSE). Principais julgados do TSE: meio século de jurisprudência. Edição organizada pela Assessoria Especial da Presidência do TSE. Brasília: Secretaria de Documentação e Informação, 2001. Disponível em: $<$ http://www.tse.jus.br/hotsites/catalogo-

publicacoes/pdf/principaisJulgados/PrincipaisJulgados_tomol.pdf>. 